\title{
Particle export from the upper ocean over the continental shelf of the west Antarctic Peninsula: \\ A long-term record, 1992-2007.
}

\author{
By \\ Hugh W. Ducklow ${ }^{1 *}$ \\ Matthew Erickson ${ }^{1}$ \\ Joann Kelly ${ }^{2}$ \\ Martin Montes-Hugo ${ }^{3}$ \\ Christine A. Ribic ${ }^{4}$ \\ Raymond C. Smith ${ }^{5}$ \\ Sharon E. Stammerjohn ${ }^{6}$ \\ David M. Karl ${ }^{7}$
}

1. The Ecosystems Center, MBL, Woods Hole, MA 02543 USA

2. Univ. of N. Carolina-Wilmington, NC, USA

3. Rutgers University, New Brunswick, NJ USA

4. University of Wisconsin-Madison, WI USA

5. University of California-Santa Barbara, CA USA

6. Lamont-Doherty Earth Institute, Palisades, NY USA

7. University of Hawaii, Honolulu, HI USA

*Corresponding author, email hducklow@mbl.edu.

Submitted to Deep-Sea Research Part II

21 June 2007

Revised: 15 March, 2007

Accepted: 25 March 2007 


\begin{abstract}
We report on results of a long-term (1993-2007) time series sediment trap moored at $170 \mathrm{~m}$ to

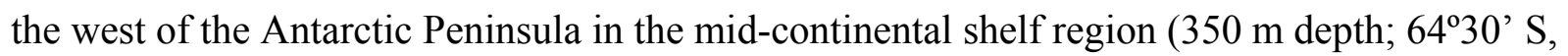
$\left.66^{\circ} 00^{\prime} \mathrm{W}\right)$. This is a region characterized by late spring-summer diatom blooms, moderately high seasonal primary productivity (50-150 $\mathrm{mmol} \mathrm{C} \mathrm{m}^{-2} \mathrm{~d}^{-1}$ in December-February) and high phytoplankton and krill biomass in the seasonal sea ice zone. The mass flux ranged from near 0 to over $1 \mathrm{~g} \mathrm{~m}^{-2} \mathrm{~d}^{-1}$ and was near 0 to $>30 \%$ organic carbon (mean $8 \%$ ). Sedimentation from the upper ocean as estimated by the trap collections at $170 \mathrm{~m}$ exhibited strong seasonality with high fluxes (1-10 mmol C m $\left.\mathrm{m}^{-2} \mathrm{~d}^{-1}\right)$ in November-March following ice retreat and very low fluxes $\left(<0.001 \mathrm{mmol} \mathrm{C} \mathrm{m}^{-2} \mathrm{~d}^{-1}\right)$ during the Austral winter and under sea ice cover. An average of $85 \%$ of the annual export of $212 \mathrm{mmol} \mathrm{C} \mathrm{m}^{-2}$ occurred during the seasonal peak flux episodes. Over the trap record, the annual peak flux episode has tended to occur later in the Austral summer, advancing by about 40 days since 1993 . The time-integrated sedimentation during the peak flux episode was $<1-50 \%$ of the SeaWiFS-estimated primary production (mean $4 \%$ ) at the trap site over the period 1998-2006. The elemental composition of material captured in the traps had an average C:N:P of 212:28:1, greater than the canonical Redfield values. High C:P ratios (400600) corresponded with the annual flux peak, indicating preferential loss of $\mathrm{P}$ from the sinking particles in the summer, ice-free period. The composition of the exported material more closely approximated the Redfield composition during the low-flux, winter period.
\end{abstract}




\section{Introduction}

Globally, continental shelves are regions of intensified biological activity and biogeochemical cycling (Smith and Hollibaugh, 1993; Liu et al., 2000; Robinson et al., 2004). Two reflections of high biogeochemical activity over continental shelves are large vertical sedimentation fluxes (Walsh et al., 1981; Walsh, 1988) and deep drawdown of $\mathrm{pCO}_{2}$ (Cai et al., 2003; Ducklow and McCallister, 2004), together constituting the "continental shelf pump," a potentially important mechanism of $\mathrm{CO}_{2}$ storage in the ocean carbon system (Tsunogai et al., 1999; Chen et al., 2003). Like other continental shelf systems, polar shelves exhibit these same characteristics. They have seasonally high primary production (Smith Jr. and Gordon, 1997; Vernet et al., 2008), large drawdowns of $\mathrm{pCO}_{2}$ (Yager et al., 1995; Takahashi et al., 2002; Carrillo et al., 2004) and intense episodes of sedimentation (Wefer et al., 1988; Honjo, 1990).

Continental shelves surrounding Antarctica are also the world's richest and most extensive reservoirs of biogenic opal sediment, a consequence of high production and sedimentation of diatoms in the Antarctic polar biome (Broecker, 1982). Unfortunately, in spite of a long history of investigation, most observations of biological production and consumption, $\mathrm{CO}_{2}$ variations and sedimentation are still limited to ice-free seasons and to individual years, with few wintertime and multiyear records from which firmer generalizations and better evaluations of variability can be drawn.

The SeaWiFS ocean color sensor provides a good record of the spatial and temporal extent of the spring-summer phytoplankton bloom following sea ice retreat (Smith et al., 2008b). Smith et al's analysis showed that peak chlorophyll variations did not always conform to the simple classical model of an ice edge bloom, following the retreating ice edge. On average (1997-2004), 
the bloom was initiated 200-400 km offshore (i.e., beyond the shelf-break in the Southern Antarctic Circumpolar Current Front; SACCF) and in the southern part of our study region. The bloom migrates inshore and northwards, spreading over the continental shelf and the trap site by December. Chlorophyll concentrations ranged $1.5-3 \mathrm{mg} \mathrm{m}^{-3}$ in this period.

Moored, time-series sediment traps provide one of the few sources of continuous information on ecosystem and biogeochemical dynamics in ocean systems, especially in Arctic and Antarctic sea ice zones where seasonal ice cover frequently limits the use of other in situ sensors and remote sensing of ocean color to the ice-free, summer seasons. Particle sedimentation integrates ecosystem processes in the upper ocean (e.g., primary and new production, consumption, net community metabolism, particle aggregation and diagenesis) and often provides the only yearround signal of biological activity in the surface layer of polar oceans. Many short-term studies of upper ocean sedimentation in Antarctic marginal ice zones suggest highly episodic and often very large fluxes of biogenic matter in summer during the ice-free period of high primary production (see, e.g., review of many pre-1990 studies in Karl et al. 1991b; 1996). The few yearround or multiyear records indeed demonstrate strong seasonal flux episodes and often very low fluxes during winter, ice-covered periods (Wefer et al., 1988; Dunbar et al., 1989; Cripps and Clarke, 1998; Collier et al., 2000; Honjo et al., 2000), with some exceptions to this pattern (Baldwin and Smith, 2003; Smith et al., 2007).

Few sediment trap studies, however, have been conducted over more than one year at a time. Observations of environmental forcing and many other ecosystem processes demonstrate that interannual variability is a dominant property of Antarctic continental shelf systems (e.g., Martinson et al., Stammerjohn et al., Smith et al., Ross et al., Vernet et al., Clarke et al. this volume). Lampitt and Antia (1997) suggested that high seasonality and great interannual 
variability may be the characteristic features of export fluxes in the Southern Ocean, rather than their overall magnitude. In their recent review, Boyd and Trull (2007) concluded that there have not been sufficient long-term records to reach a firm conclusion, and they recommended more time-series observations in undersampled regions.

The Palmer Long-Term Ecological Research Project (PAL-LTER or PAL; (Smith et al., 1995; Ross et al., 1996; Smith et al., 2003a; Smith et al., 2003b; Ducklow et al., 2006a) has since 1993 conducted annual summer (January) cruises in its $80,000 \mathrm{~km}^{2}$ study region in the Bellingshausen Sea to the west of the Antarctic Peninsula. During the cruises, a suite of hydrographic and ecological properties and processes have been measured regularly at a fixed grid of stations, and a moored time-series sediment trap has been deployed each year. In this paper we report on the long-term record of particulate organic carbon, particulate nitrogen and phosphorus flux at 170 meters, approximating the export of biogenic particles out of the surface layer at a site on the mid-continental shelf in the northern part of the PAL study area. A preliminary report on the carbon flux through 2004 was given in Ducklow et al. (2006b). Here, the record has been extended through 2006, and the full set of observations on C, N and P fluxes is presented and discussed.

\section{Methods and Materials}

\subsection{Sediment traps and deployments}

Time-series sediment traps (PARFLUX Mark 78H 21-sample traps, McLane Research Labs, Falmouth MA) have been deployed on the continental shelf off the west Antarctic Peninsula since November, 1992 (Table 1). The bottom depth at the deployment site is $350 \mathrm{~m}$ at a nominal location of 64'30' south latitude, $66^{\circ} 00^{\prime}$ ' west longitude, $130 \mathrm{~km}$ offshore in the midshelf region 
(Figure 1; LTER Grid coordinates 585.129; Waters and Smith, 1992). The moorings are deployed with the trap suspended at $170 \mathrm{~m}$ in the water column. Before each deployment, the allplastic sample cups were rinsed with Milli-Q deionized water and filled with a solution of $7.5 \mathrm{~g}$ $\mathrm{NaCl} \mathrm{L}{ }^{-1}$ and $2 \%$ borate-buffered formalin in filtered seawater. The moorings were deployed keeping the trap vertical at all times.

Since November, 1992 we have obtained 13 complete calendar-year-long records of sedimentation flux through December 2006 (Table 1). Traps were usually deployed and recovered during the Austral summer, with most deployments covering a full annual cycle. During the first 3 years, duplicate traps and multiple moorings were deployed ca 5-10 km apart. Sampling intervals varied from 4 to $61 \mathrm{~d}$, with shorter intervals during the expected period of peak flux in summer (Figure 2 and see below). There were gaps of 0-30 d between mooring recoveries and subsequent deployments (Table 1). Duplicate traps moored at the same site showed similar patterns of flux over the year (Figure 2 and Supplemental Material). Traps moored in two different locations (Palmer Basin and Crystal Sound, Table 1) showed rather different seasonal patterns, but had similar fluxes (Figure 2 and Supplemental Material). All trap results were averaged to provide a more comprehensive view of sedimentation in the Palmer region.

\subsection{Sample processing and analysis.}

Upon recovery, the trap samples were sealed and held at $5^{\circ} \mathrm{C}$ until return to the laboratory for processing. Samples were split and analyzed at the University of Hawaii (UH) until 2002 and subsequently at VIMS. All samples were gently rinsed through $1000 \mu \mathrm{m}$ Nitex ${ }^{\circledR}$ mesh using extra sample cup filling solution in order to remove large swimmers. The meshes were examined and rinsed several times to dislodge adhering organic aggregates and fecal material from the 
swimmer carcasses. The swimmer material retained on the rinsed mesh was resuspended in clean rinsing solution, examined closely and agitated gently to separate any remaining aggregate material which was then added to the final sample. The screens and retained zooplankton remains are archived refrigerated in $2 \%$ formaldehyde. These $>1 \mathrm{~mm}$ samples include krill and copepod carcasses and small gelatinous organisms. The prescreened sediment trap contents were split at UH using a PARFLUX Wet Sample Divider (McLane Research) and at VIMS using a plankton splitter. Samples from heavy flux periods were split up to $1 / 512$ for subsequent analysis. Half of each trap sample (except some cups with insufficient amounts of sediment) has been archived in formalin and stored at $5^{\circ} \mathrm{C}$.

Trap samples were assayed for total mass dry weight (DW), particulate organic carbon (Corg), particulate nitrogen $(\mathrm{N})$ and particulate phosphorus $(\mathrm{P})$. The detailed methods for the analyses are described in the JGOFS Protocols (Knap et al., 1994). After filtration, the samples for $\mathrm{CHN}$ analysis were treated with dilute $\mathrm{HCl}$ to remove inorganic carbon. $\mathrm{C}$ and $\mathrm{N}$ were analyzed on CHN Analyzers at UH or VIMS, while $\mathrm{P}$ was determined by high-temperature combustion and $\mathrm{HCl}$ extraction (Karl et al., 1991a) followed by analysis of soluble reactive phosphorus (Karl and Tien, 1992). \% Organic carbon content is $100 * \mathrm{mg}$ Corg/mg DW. Up to 3 replicate analyses of selected chemical properties were performed on each sample. To compose the main time series, analytical replicates were averaged for each trap sample, and samples were averaged for corresponding intervals if multiple traps were deployed.

\subsection{Sea ice, ocean color and other data.}

Sea ice coverage data (\% coverage) were extracted from the NASA Scanning Multichannel Microwave Radiometer (SMMR) and the Defense Meteorological Satellite Program's (DMSP) 
Special Sensor Microwave/Imager (SSM/I) satellite record for a circular region of radius 12.5 $\mathrm{km}$ around the trap location, following protocols described in Stammerjohn et al. (2008). Ice coverage data for the more extensive area of the North Shelf region of the Palmer LTER study area (Stammerjohn et al. 2008) gave the same overall pattern, with some difference in the finescale temporal variability.

Spaceborne estimations of $\mathrm{PP}_{\mathrm{eu}}$ were obtained from monthly composites of satellite-derived Chl (SeaWiFS, Sea-viewing Wide Field-of-view Sensor, $4.5 \mathrm{~km}$ spatial resolution, Montes-Hugo et al., 2007; Smith et al. 2008), $E_{o}$ (SeaWiFS, L3-level, $9 \mathrm{~km}$ spatial resolution, http://oceancolor.gsfc.nasa. gov/cgi/level3.pl), and sea-surface temperature (AVHRR, (Advanced very high resolution radiometer, channel 4-5, $4 \mathrm{~km}$ resolution, ftp://podaac.jpl.nasa.gov/sea surface temperature/avhrr/pathfinder/data_v5/). Depth-integrated net primary production within the euphotic zone $\left(\mathrm{PP}_{\text {eu }}\right)$ over the trap site was calculated using a vertical generalized production model (VGPM; Behrenfeld and Falkowski, 1997a,b) and assuming photoinhibition. Since VGPM is a global algorithm, $\mathrm{PP}_{\text {eu }}$ estimations $\left(\mathrm{mgC} \mathrm{m}^{-2} \mathrm{~d}^{-1}\right)$ were adjusted for the WAP region using local parameters (Dierssen et al., 2000).

JGOFS sediment trap data for the Ross Sea and BATS were obtained from http://usjgofs. whoi.edu/jg/dir/jgofs/. The sediment trap and related data are available at: http://oceaninformatics.ucsd.edu/ datazoo/pallter/datasets.

\section{Results}

\subsection{Flux variability}

Sediment trap deployments over the past 14 yr showed a consistent temporal pattern, with a strong flux peak in the late-spring to summer period, following ice retreat (Figure 3). Peak daily 
mass fluxes caught in sample cups deployed over 4-7 days in the Austral spring-summer ranged from $100-1500 \mathrm{mg} \mathrm{m}^{-2} \mathrm{~d}^{-1}$ (Figure 3A); or 1-10 mmol C m $\mathrm{m}^{-2} \mathrm{~d}^{-1}$ (Figure 4A). Overall, the mass flux ranged almost 4 orders of magnitude, from 0.004 to $1464 \mathrm{mg} \mathrm{m}^{-2} \mathrm{~d}^{-1}$. The composition of the sedimenting material ranged from $<1$ to $>30 \%$ organic carbon (Figure $3 \mathrm{~B}$ ).

There was also considerable interannual variability in the flux, even though every year in the record was characterized by the spring-summer peak and very low winter values. Most of the annual flux was during the peak episode (see below), which varied in size and duration (14-220 days). Annual fluxes were integrated from January to January and July to July. The former approach approximates the deployment period but often split the flux peak between two succeeding years. Integration over the July to July period avoids this difficulty, placing one entire peak in each annual accumulation. However missing data resulting from trap failure in 2001-02 (Table 1) prevented integration over the July to July periods in both 2001 and 2002; whereas January to January integration only missed 2001 (Figure 3). The January and July integrations yielded similar patterns of annual flux (Figure 5). The annual (Jan-Jan) carbon flux averaged $212 \mathrm{mmol} \mathrm{C} \mathrm{m} \mathrm{a}^{-2}$, ranging over more than an order of magnitude, from 13-344 mmol $\mathrm{C} \mathrm{m}^{-2} \mathrm{a}^{-1}$ (Table 2).

We quantified the within-season variability of the flux using a modified Flux Stability Index (FSI; Lampitt and Antia 1997). The FSI is the number of days it takes the accumulated flux to reach half the annual total. Lampitt and Antia (1997) note that the FSI should only be applied where fluxes have little interannual variability, which is clearly not the case here. In our record, the flux accumulates $50 \%$ of the annual total in a short period, but applying a start date for the calculation is problematic: sometimes it is late in the calendar year, and sometimes early in the next year; and it has been shifting (Table 3). These differences will lead to large variations in 
the FSI if a fixed date in a calendar year is used. We addressed the problem by calculating the FSI considering that the "flux year" starts at the beginning of one annual peak and extends until the start of the next peak (peak period defined below). FSI calculated in this way averaged $55 \pm 10$ days (Table 3). If the flux were uniform through a year the FSI would be 183 days. The low value indicates the extreme seasonality in our record.

\subsection{Temporal patterns and seasonality}

To evaluate the timing and importance of the peak flux episode in each year, we identified the period of time when the flux continuously exceeded $0.2 \mathrm{mmol} \mathrm{C} \mathrm{m}^{-2} \mathrm{~d}^{-1}$ for $14 \mathrm{~d}$ or more. These periods, including the date of the maximum flux in each year, are presented in Table 3. Fluxes tended to increase rapidly in the Austral spring, and declined more gradually after the peak flux period (Figure 4), yielding a pattern with an abrupt rise and a tail of moderate to low fluxes in the summer-autumn period. On average $85 \%$ of the annual flux came down during the peak periods which averaged 106 days in duration; that is, most the annual flux accumulated during less than one-third of the year in the spring-summer period (Table 3).

The timing of the peak flux period appears to be shifting over time (Figure 6, Table 3). We divided the record into two parts at 1997-98 because a large ENSO event in 1998 appeared to cause long-lasting perturbations throughout the marine system in this region (Martinson et al., 2008; Stammerjohn et al., 2008). During the first five years of the time series, the peak commenced on average on 08 December and ended on $25 \mathrm{March}$, lasting $106 \mathrm{~d}$. The maximum flux occurred between 14 Dec and 31 Jan (avg 03 Jan). In the last 6 years, the start and end date for the peak period shifted by a month (starting 8 Jan, ending 23 Apr), with no change in overall duration (Table 3). The date of the observed maximum peak shifted by 42 days (from 3 Jan to 14 Feb). We tested hypotheses that the dates of peak start, maximum flux ("peak day"), and peak 
end were different in these two periods (see Supplemental Materials section). Both peak start (t-test, unequal variances; $\mathrm{p}<0.05)$ and peak day $(\mathrm{p}<0.01)$ differed significantly. Neither peak end, peak duration nor the peak height differed significantly during the two periods. Thus the peak flux period, containing $85 \%$ of the annual sedimentation, is shifting to later in the season. This may be related to declining duration and extent of sea ice coverage in the region (see Discussion).

\subsection{Elemental composition}

The organic carbon (Corg) flux was proportional to the mass flux, but increased more slowly at high mass fluxes (Figure 7). The 3 samples with mass flux $<400 \mathrm{mg} \mathrm{m}^{-2} \mathrm{~d}^{-1}$ but high Corg $>$ $60 \mathrm{mgC} \mathrm{m} \mathrm{m}^{-2} \mathrm{~d}^{-1}$ occurred during the two annual highest flux events (hyperblooms; 1995 and 2006, Figure 5), when Corg was $16-30 \%$ of the total mass. Corg averaged $5 \%$ of the total mass flux during high flux periods (mass flux $>400 \mathrm{mg} \mathrm{m}^{-2}$ ) but $10 \%$ at fluxes $<400 \mathrm{mg} \mathrm{m}^{-2} \mathrm{~d}^{-1}$ Total mass and Corg fluxes co-occurred throughout the record (cf. Figures 3A, 4).

The time-integrated or mass-weighted average elemental composition of the sedimentation flux captured over the year was 212:25:1 (Table 2), somewhat above the Redfield ratio of 106:16:1, indicating that sinking particles are phosphorus-poor and depleted in nitrogen relative to carbon. These bulk ratios reflected the elemental composition of the individual samples, which had an average C:N:P ratio of 209:25:1 (Figure 8). C:N composition was least variable (Figure $8 \mathrm{~A}, \mathrm{r}^{2}=0.97$ ), while the $\mathrm{C}: \mathrm{P}$ and $\mathrm{C}: \mathrm{N}$ composition were more variable (Figures 9B,C). The N:P and C:P ratios of the annual fluxes varied by factors of 4 and 3 , respectively (Table 2 , discounting the anomalous $2004 \mathrm{P}$ values).

The variability in $\mathrm{C}: \mathrm{P}$ ratios is also reflected in the temporal behavior of the elemental composition of the sedimentation flux (Figure 9). In Figure 9A the carbon flux is plotted on a 
$\log$ scale to emphasize the period of low fluxes. The C:N ratio was relatively uniform over time, without well-defined, repeating peaks. In contrast, the C:P ratio time series reveals strong periodic behavior, with peak values in most years corresponding to the period of peak carbon flux, and lower values approximating the Redfield ratio and corresponding to the low-flux period. Thus the annual pattern of the sedimentation flux appears to be characterized by a period of high, carbon-rich and phosphorus-poor particles, and a longer period of very low sedimentation with near-Redfield elemental composition.

\subsection{Phytoplankton blooms, primary production and export ratios.}

In situ data on chlorophyll concentrations and primary production in the mooring vicinity are only available during January-February during annual research cruises (Vernet et al., 2008). SeaWiFS observations provide a wider picture of temporal and spatial variability. SeaWiFS estimates of surface chlorophyll (Figure 3B) show that a phytoplankton bloom (Chl $\geq 0.5 \mathrm{mg}$ $\mathrm{m}^{-3}$ ) occurred over the trap site in most, but not all years for which data were available (Smith et al. 2008). Notable blooms at the trap location were captured by SeaWiFS in 1997-98, 99-00, 0405 and 05-06. Smaller blooms, or incomplete data obscuring the full bloom sequence occurred in 00-01, 01-02 and 03-04. No bloom was evident to SeaWiFS in 98-99 and 02-03. These same bloom or nonbloom events are consistent with the larger-scale, more comprehensive analysis by Smith et al (2008). The eight-year record in the SeaWiFS period (1998-2007) is not long enough to draw any conclusion regarding a relationship between the phytoplankton bloom and flux episodes. In general, however, the annual sedimentation peak either corresponded in time, or followed the bloom by as much as $2-4$ months. There was no clear relationship between the amplitudes of the blooms and sedimentation peaks. 
SeaWiFS-based estimates of primary production rates over the sediment trap site ranged from 5-204 mmol C m${ }^{-2} \mathrm{~d}^{-1}$ during the December-February period (80 days) when lack of sea ice cover permits remotely-sensed estimates of PP (Table 4). For comparison, the corresponding peak sedimentation fluxes ranged from $0.2-4.3 \mathrm{mmolC} \mathrm{m}^{-2} \mathrm{~d}^{-1}$. The ratio between the satelliteestimated PP over the trap site and the flux captured in the sediment traps was 0.04 when the sedimentation was extrapolated from 170 to $60 \mathrm{~m}$ (average euphotic zone depth), using a scaling factor derived from previous studies (Table 4).

\section{Discussion}

\subsection{Seasonality of sedimentation and export flux.}

Two conspicuous aspects of sedimentation in Antarctic marginal ice zone (MIZ) waters are the markedly episodic nature of the annual sedimentation pulse, and the wide range of sedimentation rates observed over the course of a year (Wefer et al., 1988). Most sites in the Antarctic MIZ exhibit an annual pulse of sedimentation during the ice-free season following ice retreat (Fischer, 1988; Honjo et al., 2000), and this phasing is particularly evident in our 14-year record (Figure 3). In the Bransfield Strait in 1983-4, about $70 \%$ of the annual flux occurred in a single month (January; Figure 10 and Wefer et al. 1988). This pattern resembles the flux at our site in 1997, the year with the lowest annual flux we observed (Figure 5, Table 2). In contrast, the sedimentation peak in the Ross Sea occurred later, after sea ice advance in April-May (Figure 10 and Collier et al. 2000).

The extreme seasonality of sedimentation in Antarctica is in contrast to the annual pattern at mid-latitude sites like the BATS site off Bermuda, a system also characterized by a spring phytoplankton bloom (Figure 10). At BATS, the decadal mean flux is more evenly distributed 
over the year. The mean FSI for Bermuda (1989-2006) is 155 \pm 12 days, indicating much lower seasonality than at the Palmer site. The flux in the Ross Sea (in a single-year record) appears to be intermediate between the other Antarctic sites and Bermuda, but the long sampling interval between May and October, 1997 may have obscured a longer-term pattern (Figure 10). Large interannual variability in the annual flux pattern (Table 2) makes generalization from shorter deployments inadvisable. The seasonal pulse in any given year can depart greatly from the longer-term mean, and the extreme concentration of the sedimentation in a single brief pulse (as in the Bransfield Strait) may not be representative over a longer term (Figure 10). The relatively low long-term mean of the annual peak in our study derives from temporal variability in the timing of the pulse event, not the absolute magnitude of the pulses. There was a strong pulse in most years (Figure 3), but it happened any time between mid-December and mid-March (Table 3), blurring the amplitude in the long-term mean. The mean amplitude of all the annual pulse events (ignoring time of occurrence) was $4.3 \mathrm{mmol} \mathrm{C} \mathrm{m}^{-2} \mathrm{~d}^{-1}$, about twice as great as the mean pulse shown in Figure 10, and about the same as in the single pulse observed in the Ross Sea. The same averaging effect can be observed in the BATS record (Steinberg et al. 2001). The pulsed nature of the annual flux pattern appears to be associated with lower total annual fluxes than regimes where the flux is more evenly distributed over the year. For example the flux into our trap was lowest in 1997, the most strongly seasonal year we observed, and the other sites with strongly periodic fluxes (Weddell Sea and Bransfield Straits) also had low annual totals (Table 5; Figure 10).

We observed that the annual sedimentation peak is now occurring later in the season than it did in the first years of our deployments (Table 3, Figure 6). This effect may be a response of the biogeochemical system to climate-driven changes in the western Antarctic Peninsula region. In 
the Palmer-Faraday-Vernadsky Station region $\left(\mathrm{ca} .65^{\circ} \mathrm{S}, 64^{\circ} \mathrm{W}\right)$, the mean annual surface atmospheric temperature has increased by $0.05^{\circ} \mathrm{C}$ per year since 1950 (Ducklow et al., 2006a). The warming has been strongest in winter (June-August), warming by $6.3^{\circ} \mathrm{C}$ in the past 50 years (Vaughan et al., 2003). The warming, coupled with changes in atmospheric and ocean circulation, has resulted in a $30 \%$ loss of sea ice extent and a decline of 85 days in the duration of ice cover since 1978 (Stammerjohn et al., 2008). Sea ice in the LTER study region now retreats earlier, and advances later, than it did 25-30 years ago at the beginning of the satellite record of sea ice extent. The reason that the sedimentation peak might be migrating in response to a change in sea ice cover is not clear. Vernet et al. (2008) found a significant positive relationship between both the ice coverage and date of sea ice retreat and the magnitude of primary production (PP) observed during January (1995-2006). That is, the longer the duration of ice cover and the later the retreat, the greater the PP during January-February. Earlier ice retreat, which is indicated by the trend in our observations, is not thought to cause earlier or larger phytoplankton blooms (Arrigo et al., 1998). The reason is that early season PP is inhibited by light availability, wind and deep mixing. If ice retreat is later, when winds tend to be lower, surface layer nutrient concentrations are still high, and PP is enhanced. There was no relationship of PP with the date of ice advance. Declining ice duration may allow a longer growing season and later export, but the effect cannot be discerned from our observations. If it continues, the shift in the peak sedimentation flux could influence benthic organisms dependent on sedimentation for energy and nutrition.

The other notable aspect of our record, in common with other observations in the MIZ, is the extreme low value of fluxes in the winter (ice-covered) season. We observed extended periods when fluxes were as low as $0.003 \mathrm{mmolC} \mathrm{m}^{-2} \mathrm{~d}^{-1}$ (e.g., March-Dec, 1997), comparable to low 
fluxes observed by Wefer et al. (1988), though not as low as those documented by Fischer et al. (1988) in the southern Weddell Sea (Table 5). The values are much lower than the lowest values

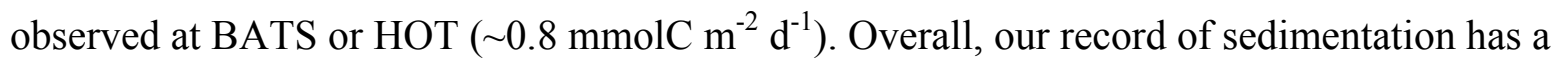
large range of over 3 orders of magnitude in average daily $\mathrm{C}$ flux, and well over an order of magnitude in annual flux (Figure 5). The mass flux had greater Corg content (10\%) during low flux periods than high (5\%). This pattern suggests that the organic sedimentation is diluted by ice-rafted lithogenic material during the peak flux periods following the ice retreat. In contrast, the mass flux is very low, with higher \% Corg in winter (Figures 3,7) and the particles approximate the Redfield ratio (Figure 9). Together these observations suggest that the sea ice efficiently retains its particle load until the period of ice retreat, after which increased biological activity in open water results in particle transformation and export (e.g., Figure 9C).

Annual fluxes at BATS vary by a factor of 3 (Steinberg et al. 2001). The lower seasonality at Bermuda (lower peak, higher off-peak fluxes) yield an annual flux more then twice as great as the Antarctic sites (Table 5). Baldwin and Smith (2003) deployed a time-series trap at $160 \mathrm{~m}$ in the semienclosed Port Foster Bay inside Deception Island to the north of our study site. They observed a seasonal pattern with high fluxes (1-10 mmol C m $\left.\mathrm{m}^{-1}\right)$ in the Austral winter. These values are equal to the fluxes we observed in summer. Their collection cups were clogged by presumably very high fluxes in February to May, 2000, thus obscuring the full annual cycle. Extrapolated fluxes from in situ sediment respiration measurements suggested peak fluxes approaching $20 \mathrm{mmol} \mathrm{C} \mathrm{m} \mathrm{d}^{-2}$. A time-series trap was deployed by the FOODBANCS Project (Smith et al., 2006, 2008a) in $1999-2000$ at $64.8^{\circ} \mathrm{S}, 65.34^{\circ} \mathrm{W}$, about $50 \mathrm{~km}$ inshore of our trap, but in deeper water $(610 \mathrm{~m})$. This trap moored at 150-160 $\mathrm{m}$ above the bottom (ca. $450 \mathrm{~m}) \mathrm{had}$ 
four collection periods lasting 90-120 days, but still reveals a seasonal pattern as described above

(Table 6). However the fluxes were generally larger than we observed, especially in winter.

\subsection{Intensity and composition of the export flux.}

The export ratio (e-ratio; sedimentation divided by primary production over a specified time interval) is an index of the efficiency at which the primary production is exported from the upper ocean or euphotic zone, by various processes (Ducklow et al., 2001). It may range from $<2$ to $>50 \%$ depending on the interval, location and other factors (Buesseler, 1998). Generally the export is thought to be dominated by particle sedimentation, although in some locations the advection and mixing of dissolved organic matter can be about equal to the sinking term (Carlson et al., 1994). Our traps were moored well below the depth of the summer mixed layer $(57 \pm 16 \mathrm{~m} ; \mathrm{n}=78)$ and summer euphotic zone $(36 \pm 19 \mathrm{~m} ; \mathrm{n}=78)$, near the base of winter mixed layer $(100 \pm 30 \mathrm{~m} ; \mathrm{n}=78)$ in this area (Martinson et al., 2008). The apparent export ratio, estimated for December to February when the average flux at 170 meters is near its peak value was very low, averaging just $4 \%$ (Table 4 ). This calculation was derived by comparing the flux in the sedimentation peaks (Table 3) with the December to February PP, roughly assuming a one-month lag between production and export. In the Ross Sea, PP ranged from $52 \mathrm{mmol} \mathrm{C} \mathrm{m}^{-2}$

$\mathrm{d}^{-1}$ in January, 1997 to $1.3 \mathrm{mmol} \mathrm{C} \mathrm{m}^{-2} \mathrm{~d}^{-1}$ in April (Smith Jr. et al., 2000). The same calculation of the export ratio for the Ross Sea yields a comparable estimate of 5\%. If we estimate that the cumulative sedimentation flux episode of $\sim 220 \mathrm{mmol} \mathrm{C} \mathrm{m}^{-2}$ during March to May (see Figure 10) was derived from the January-February PP of $2.5 \mathrm{Mol} \mathrm{C} \mathrm{m}^{-2}$ (integrated assuming a linear decrease in PP from 10 Feb to 14 April; (Ducklow, 2003)), the export ratio during the late summer in the Ross Sea was $(0.22 / 2.5$ moles C) or about $9 \%$. At BATS, the average PP for December-February and sedimentation flux for the January-March interval (characteristic of the 
phytoplankton bloom period there) were 4 and $0.24 \mathrm{~mol} \mathrm{C} \mathrm{m}^{-2}$, yielding an export ratio of $6 \%$ for $170 \mathrm{~m}$. At BATS, the average annual e-ratio for 1988-97 ranged from 4-8\% (mean 6\%). An accurate annual e-ratio for the Antarctic seas cannot be calculated, unless it is assumed that the (unknown) production by sea ice communities and underice production are entirely negligible.

Karl et al. (1991b) observed short-term (24-36 hr) fluxes into free-floating sediment traps deployed at 100 and 200 meters in the Gerlache Strait, $\sim 80 \mathrm{~km}$ inshore and $\sim 300 \mathrm{~km}$ northeast of our study area. Carbon fluxes ranged from 2-30 mmol C m $\mathrm{m}^{-2} \mathrm{~d}^{-1}$ between December and March (1.4 Mol $\mathrm{C} \mathrm{m}^{-2}$ for the season), with little systematic difference between the 100 and 200 meter collections. Only their lowest values were comparable to our observations from further offshore. They estimated a seasonal (January-March) net community production of $8.4 \mathrm{Mol} \mathrm{C} \mathrm{m}^{-2}$ from the net drawdown of $\mathrm{TCO}_{2}$, and from that derived an e-ratio for carbon of $17 \%$. In their review of 32 other sediment trap studies made during the 1980's, they noted numerous examples of high fluxes in the Austral summer, with peak fluxes averaging $14 \mathrm{mmol} \mathrm{C} \mathrm{m}^{-2} \mathrm{~d}^{-1}$ (range $<1-117$ mmol $\left.\mathrm{C} \mathrm{m}^{-2} \mathrm{~d}^{-1}\right)$. Most, but not all of these were from inshore locations, and all fluxes $>15 \mathrm{mmol}$ $\mathrm{C} \mathrm{m} \mathrm{m}^{-2} \mathrm{~d}^{-1}$ were from the Bransfield Strait or other nearshore sites. More recently (Anadon et al., 2002) deployed similar floating traps at $60 \mathrm{~m}$ in the Bransfield-Gerlache Straits area, observing fluxes ranging from 8-67 mmol $\mathrm{C} \mathrm{m}^{-2} \mathrm{~d}^{-1}$. From these fluxes and concurrent observations of PP they estimated e-ratios at $60 \mathrm{~m}$ of $16-40 \%$. These equate to e-ratios of $7-26 \%$, similar to the seasonal scale estimate of Karl et al (1991b) when scaled to $170 \mathrm{~m}$ with the Martin exponent of -0.858 .

In spite of the similarity of our apparent e-ratios to those in the Ross Sea, the low values raise the possibility that our moored conical traps are poor collectors of the export flux in this region. The various complications and shortcomings of sediment traps as flux collectors are well-known 
(Buesseler, 1991; Gardner, 1999). Several factors may lead to low trapping efficiencies. The most important is current shear over the trap opening at current velocities above ca. $22 \mathrm{~cm} \mathrm{~s}^{-1}$. We do not have current information for the mooring site, except for brief periods when the research vessel is nearby. Current drifter observations (unpublished data) and acoustic Doppler current profiling data (C. Smith, Univ. Hawaii, personal comm.) indicate that high current velocities can penetrate to the trap depth. We note that when we deployed replicated traps near each other, they yielded similar patterns and values for the fluxes, whereas more remote traps could differ substantially (Figure 2 and Supplemental Materials). The replicate trap results suggest that purely random effects of hydrodynamic bias were minimal. Another factor leading to underestimation of fluxes is solubilization of particles. For example, most of the total phosphorus in trap collection cups can be found in the dissolved phase (Antia, 2005). This process could cause the high particulate C:P ratios we observed during the flux peaks (Figure 9C). We would expect however, that solubilization would be highest in preserved traps with very low particle loads rather than those with the largest collections. In any case, solubilization alone does not explain why the C:P ratios are repeatedly greater during the flux peaks, and approach the Redfield values at low flux periods, as in the winter.

Buesseler et al. (2007) reviewed the factors causing artifacts in sediment trap collections, and concluded that trapping efficiency based on predicted vs. observed capture of ${ }^{230} \mathrm{Th}$ and ${ }^{231} \mathrm{~Pa}$ by traps was lowest in upper ocean traps where swimmers and current velocity were both maximal. Extrapolation from Figure 5.5 in Buesseler et al. (2007) suggests that collection efficiency averages $\sim 10-20 \%$. Using this range of trapping efficiencies would scale our e-ratios to $20-40 \%$.

Even export ratios averaging 20-40\% may be low relative to our understanding of Antarctic coastal systems. There are few data on new production for the Palmer region. Cochlan et al. 
(1993) estimated an f-ratio of 0.87 in winter. Probyn and Painting (1985) found the f-ratio in the Scotia Sea ranged from $0.25-0.6$ but also suggested that these were overestimates because the ammonium and urea uptake rates were not corrected for regeneration. Bury et al. (1995) estimated that the f-ratio ranged from $0.11-0.86$ at 3 stations in the Bellingshausen Sea (68S, 84 W, well to the south of our study region) in Nov-Dec, 1992. In the Ross Sea in 1996-97, the fratios ranged 0.83-0.92 (Cochlan and Bronk, 2001), much higher than the e-ratios derived above. Bode et al (2002) estimated f-ratios ranging from $0.31-0.64$ in the Bransfield Strait in Dec. 1995 - January, 1996. These observations and the larger export fluxes derived from short-term floating trap deployments suggest e-ratios around $50 \%$ for this system. This value is consistent with the traditional view of Antarctic marine systems characterized by sinking diatoms, large grazers and high export efficiency.

Schlitzer (2002) used an inverse model of ocean circulation and nutrient distributions to estimate an e-ratio of $\sim 50 \%$ for the Antarctic Peninsula region. Models of foodwebs suggest lower e-ratios. Laws et al. (2000) used a simple foodweb model to estimate e-ratios as a function of PP and temperature. They estimated an e-ratio of $\sim 75 \%$ of the Ross Sea and $\sim 25-40 \%$ for the area west of the Antarctic Peninsula. An inverse model of Antarctic foodwebs combining observations in a foodweb model similar to the one used by Laws et al. (2001) suggested lower values for the e-ratio in the Antarctic Peninsula (Daniels et al., 2006) and Ross Sea (Ducklow et al., 2006b) systems in the vicinity of the sediment traps. The model uses an inverse approach with observations on phytoplankton and bacterial stocks and production rates, export into the traps, krill and penguin stocks. The model solution for each intercompartmental exchange was constrained to be within $\pm 50 \%$ of the observed value (if available). The model solutions suggested surprisingly large reliance on regenerated nutrients and low export via sedimentation, 
compared to the traditional view of Antarctic foodwebs as articulated above. The e-ratio was 9\%, somewhat higher than our observations, but much lower than the observations quoted above. The high-recycling, low-export system described by the inverse foodweb model was driven by intense reingestion of detrital carbon. Fluxes to the sinking detrital pool totaled $25 \%$ of the PP, but detritus ingestion by protozoans, microzooplankton and krill amounted to $16 \%$, leaving $9 \%$ for export (Daniels et al., 2006). Krill may fragment sinking particles (coprohexy; coprophagy), slowing sedimentation velocities and allowing more time for decomposition during transport (Turner, 2002; Povero et al., 2003).

Intense recycling and processing of exported particulate matter during the flux peaks is also indicated by the elemental composition data. The particles intercepted by the traps tended to be carbon-rich suggesting efficient remineralization of $\mathrm{N}$ and especially $\mathrm{P}$. The high C:P ratios during the flux peaks (Figure 9C) suggest rapid loss of P by foodweb processes in the upper 170 $m$ during the peak flux period, consistent with the inverse models of summer foodwebs. High reworking and turnover of organic matter stocks is not consistent with a view of high-latitude systems dominated by sinking of ungrazed diatoms or phytodetritus. But in the summer period the shelf region off the Antarctic Peninsula can harbor large populations of krill, salps and other grazers (Ross et al. 2008) to transform phytoplankton biomass. In this season, more intensive reworking of sinking particulate matter in not unexpected. Short-term process studies near the mooring site utilizing floating sediment traps and radioisotopic tracers will help to understand this system better.

The results presented here raise several issues requiring further investigation. Moored sediment traps are influenced by several factors that can impact their collection efficiency, such as current shears. Moored traps are also one of the only observation systems providing year- 
round, continuous monitoring of ecosystem functions in remote polar, ice-covered systems. It is important to provide better understanding of the potential artifacts and better constrain the collection efficiency. Another high priority is understanding the factors governing the large interannual variability in the annual fluxes. At present with $n=13$, the interannual variation is not consistently related to sea ice, primary production or zooplankton. There are still relatively few continuing, long-term trap moorings, and even fewer attempts to analyze the interannual variability. In a system undergoing rapid change the controlling factors may themselves be changing, making it more difficult, and more critical, to understand the mechanisms regulating flux variability. Finally, the trend in date of flux peak occurrence will be better established, or possibly revealed to be a short-term anomaly with further observations. Overall, these questions point up the utility and importance of sustained observations in polar regions, as in all parts of the global ocean.

\section{Summary}

1. The export flux in this region, as in other Antarctic coastal and seasonal sea ice zones, is highly periodic. In the WAP, the peak flux occurs following ice retreat and very low fluxes are associated with the wintertime, ice covered period. Ice advance is occurring later in the year, leading to a longer ice-free period each summer. The date of the peak export is now happening about 40 days later in the season than it did in the earlier years of the trap deployment, with potentially important implications for water column and benthic ecology.

2. Peak fluxes ranged from $1-10 \mathrm{mmol} \mathrm{C} \mathrm{m}^{-2} \mathrm{~d}^{-1}$ while the winter values were $<0.01 \mathrm{mmol} \mathrm{C} \mathrm{m}^{-2}$ $\mathrm{d}^{-1}$, a dynamic range of 4 orders of magnitude. The mean annual flux is $0.2 \mathrm{Mol} \mathrm{C} \mathrm{m}$ or about $4 \%$ of the annual primary production. Trap collection efficiency may be $<20 \%$ however, so the true value of the export ratio is uncertain. If the real e-ratio is low (e.g., $<$ 
$30 \%$ ), it suggests high-retention foodwebs with high regeneration efficiencies, in contrast the traditional view of Antarctic foodwebs.

3. Elemental composition of the exported material captured in the sediment trap averaged C:N:P of 212:25:1, also indicating efficient regeneration of $\mathrm{N}$ and $\mathrm{P}$ (particularly $\mathrm{P}$ ) from the falling particles. Very high C:P ratios (400-600) accompanied and strongly corresponded with the time of the peak flux, suggesting intensive P regeneration in the Austral summer. $\mathrm{C}: \mathrm{N}: \mathrm{P}$ in winter was close to the Redfield values.

\section{Acknowledgements}

This research was supported by NSF Grants OPP 9011927,9632763 and 0217282 for the Palmer Long Term Ecological Research project. HWD thanks Ken Buesseler (WHOI) for discussion of sediment trap technology. We thank many members of the logistics support groups at Antarctic Support Associates and Raytheon Polar Services, and the officers and crews of the Polar Duke and Laurence M Gould, without whose excellent assistance this work could not have been accomplished. Terry Houlihan (1992-1997) and Chris Carrillo (1998-2002) supervised University of Hawaii sediment trap deployments. Ursula Magaardf (1992-2002) and Helen Quinby (2003-2006) supervised sample analyses at UH and VIMS, respectively. 


\section{References.}

Anadon, R., Alvarez-Marques, F., Fernandez, E., Varela, M., Zapata, M., Gasol, J.M., Vaque, D., 2002. Vertical biogenic particle flux during Austral summer in the Antarctic Peninsula area. Deep Sea Research Part II: Topical Studies in Oceanography 49 (4-5), 883-901.

Antia, A., 2005. Particle-associated dissolved elemental fluxes, revisiting the stoichiometry of mixed layer export. Biogeosciences Discussions 2, 275-302.

Arrigo, K.R., Worthen, D., Schnell, A., Lizotte, M.P., 1998. Primary production in Southern Ocean waters. Journal of Geophysical Research. C. Oceans [J. Geophys. Res. 103 (C8), 587-515.

Baldwin, R.J., Smith, K.L., 2003. Temporal dynamics of particulate matter fluxes and sediment community response in Port Foster, Deception Island, Antarctica. Deep Sea Research Part II: Topical Studies in Oceanography 50 (10-11), 1707-1725.

Behrenfeld, M.J., Falkowski, P.G., 1997a. A consumer's guide to phytoplankton primary productivity models. Limnology and Oceanography 42, 1479-1491.

Behrenfeld, M.J., Falkowski, P.G., 1997b. Photosynthetic rates derived from satellite-based chlorophyll concentration. Limnology and Oceanography 42, 1-20.

Bode, A., Castro, C.G., Doval, M.D., Varela, M., 2002. New and regenerated production and ammonium regeneration in the western Bransfield Strait region (Antarctica) during phytoplankton bloom conditions in summer. Deep Sea Research Part II: Topical Studies in Oceanography 49 (4-5), 787-804.

Boyd, P.W., Trull, T.W., 2007. Understanding the export of biogenic particles in oceanic waters: Is there consensus? Progress In Oceanography 72 (4), 276-312.

Broecker, W.S., and T.-H. Peng, 1982. Tracers in the Sea. Eldigio Press, Palisades.

Buesseler, K.O., 1991. Do upper-ocean sediment traps provide an accurate record of particle flux? Nature 353, 420-423.

Buesseler, K.O., 1998. The decoupling of production and particulate export in the surface ocean. Global Biogeochem. Cycles 12, 297-310.

Buesseler, K.O., Antia, A.N., Chen, M., Fowler, S.W., Gardner, W.D., Gustafsson, O., Harada, K., Michaels, A.F., Rutgers van der Loeff, M., Sarin, M., Steinberg, D.K., Trull, T., 2007. An assessment of the use of sediment traps for estimating upper ocean particle fluxes. Journal of Marine Research 65, 345-416.

Bury, S.J., Owen, N.J.P., Preston, T., 1995. 13C and 15N uptake by phytoplankton in the marginal ice zone of the Bellingshausen Sea. Deep Sea Research Part II: Topical Studies in Oceanography 42 (4-5), 1225-1252.

Cai, W.-J., Wang, Z.A., Wang, Y., 2003. The role of marsh-dominated heterotrophic continental margins in transport of $\mathrm{CO} 2$ between the atmosphere, the land-sea interface and the ocean. Geophysical Research Letters 30, doi:10.1029/2003GL017633.

Carlson, C.A., Ducklow, H.W., Michaels, A.F., 1994. Annual flux of dissolved organic carbon from the euphotic zone in the northwestern Sargasso Sea. Nature 371, 405-408. 
Carrillo, C.J., Smith, R.C., Karl, D.M., 2004. Processes regulating oxygen and carbon dioxide in surface waters west of the Antarctic Peninsula. Marine Chemistry 84 (3-4), 161-179.

Chen, A.C.-T., Liu, K.K., Macdonald, R., 2003. Continental Margin Exchanges. In: Fasham, M.J.R. (Ed.), Ocean Biogeochemistry: The Role of the Ocean Carbon Cycle in Global Change. Springer-Verlag, Berlin, pp. 53-98.

Clarke, A., Meredith, M.P., Wallace, M.I., Brandon, M.A., Thomas, D.N., 2008. Seasonal and interannual variability in temperature, chlorophyll and macronutrients in northern Marguerite Bay, Antarctica. Deep Sea Research II 55, 000-000.

Cochlan, W.P., Martinez, J., Holm-Hansen, O., 1993. RACER: utilization of nitrate, ammonium and urea during Austral winter in Gerlache Strait, Antarctica. Antarctic Journal of the United States 28, 169-172.

Cochlan, W.P., Bronk, D.A., 2001. Nitrogen uptake kinetics in the Ross Sea, Antarctica. Deep Sea Research Part II: Topical Studies in Oceanography

US Southern Ocean JGOFS Program (AESOPS) - Part II 48 (19-20), 4127-4153.

Collier, R., Dymond, J., Honjo, S., Manganini, S., Francois, R., Dunbar, R., 2000. The vertical flux of biogenic and lithogenic material in the Ross Sea: moored sediment trap observations 1996-1998. Deep Sea Research Part II: Topical Studies in Oceanography 47 (15-16), 3491-3520.

Cripps, G.C., Clarke, A., 1998. Seasonal variation in the biochemical composition of particulate material collected by sediment traps at Signy Island, Antarctica. Polar Biology 20 (6), 414-423.

Daniels, R.M., Ducklow, H.W., Richardson, T.L., 2006. Food web structure and biogeochemical processes during oceanic phytoplankton blooms: An inverse model analysis. Deep-Sea Research II 53, 532-554.

Dierssen, H.M., Vernet, M., Smith, R.C., 2000. Optimizing models for remotely estimating primary production in Antarctic coastal waters. Antarctic Science 12, 20-32.

Ducklow, H.W., Steinberg, D.K., Buesseler, K.O., 2001. Upper Ocean Carbon Export and the Biological Pump. Oceanography 14, 50-58.

Ducklow, H.W., 2003. Seasonal production and bacterial utilization of DOC in the Ross Sea, Antarctica. In: DiTullio, G. (Ed.), Biogeochemical Cycles in The Ross Sea. American Geophysical Union., Washington, DC, pp. 143-158.

Ducklow, H.W., McCallister, S.L., 2004. Chapter 9. The biogeochemistry of carbon dioxide in the coastal oceans. In: Robinson, A.R., Brink, K., Rothschild, B.J. (Eds.), The Sea. Volume 13 The Global Coastal Ocean: Multiscale Interdisciplinary Processes. Harvard University Press, Cambridge, MA, pp. 269-315.

Ducklow, H.W., Baker, K., Martinson, D.G., Quetin, L.B., Ross, R.M., Smith, R.C., Stammerjohn, S.E., Vernet, M., Fraser, W., 2006a. Marine ecosystems: The West Antarctic Peninsula. Philosophical Transactions of the Royal Society of London B 362, 67-94.

Ducklow, H.W., Fraser, W., Karl, D.M., Quetin, L.B., Ross, R.M., Smith, R.C., Stammerjohn, S.E., Vernet, M., Daniels, R.M., 2006b. Water column processes in the West Antarctic Peninsula and the Ross Sea: foodweb structure and interannual variability. Deep-Sea Research II 53, 834852. 
Dunbar, R.B., Leventer, A.R., Stockton, W.L., 1989. Biogenic sedimentation in McMurdo Sound, Antarctica. Marine Geology 85 (2-4), 155-179.

Fischer, G., D. Fuetterer, R. Gersonde, S. Honjo, D.R. Ostermann, and G. Wefer, 1988. Seasonal variability of particle flux in the Weddell Se and its relation to ice cover. Nature 335, 426-428.

Gardner, W.D., 1999. Sediment trap sampling in surface waters. In: Hanson, R.B., Ducklow, H.W., Field, J.G. (Eds.), The Changing Ocean Carbon Cycle: A Midterm Synthesis of the Joint Global Ocean Flux Study. Cambridge University Press, Cambridge, U.K., pp. 240-284.

Honjo, S., 1990. Particle fluxes and modern sedimentation in polar oceans. In: Smith Jr, W.O. (Ed.), Polar Oceanography. Academic, New York, pp. 322-353.

Honjo, S., Francois, R., Manganini, S., Dymond, J., Collier, R., 2000. Particle fluxes to the interior of the Southern Ocean in the Western Pacific sector along 170W. Deep Sea Research Part II: Topical Studies in Oceanography 47 (15-16), 3521-3548.

Karl, D.M., Dore, J.E., Hebel, D.V., Winn, C., 1991a. Procedures for particulate carbon, nitrogen, phosphorus and total mass analyses used in the US-JGOFS Hawaii Ocean Time-series program. In: Hurd, D.C., Spencer, D.W. (Eds.), Marine Particles: Analysis and Characterization. American Geophysical Union, Washington, DC, pp. 71-77.

Karl, D.M., Tilbrook, B.D., Tien, G., 1991b. Seasonal coupling of organic matter production and particle flux in the western Bransfield Strait, Antarctica. Deep-Sea Research 38 (8-9A), 10971126.

Karl, D.M., Tien, G., 1992. MAGIC: A sensitive and precise method for measuring dissolved phosphorus in aquatic environments. Limnology and Oceanography 37 (1), 105-116.

Karl, D.M., Christian, J.R., Dore, J.E., 1996. Microbiological oceanography in the region west of the Antarctic Peninsula: Microbial dynamics, nitrogen cycle and carbon flux. In: Ross, R.M., Hofmann, E.E., Quetin, L.B. (Eds.), Foundations for ecological research west of the Antarctic Peninsua. American Geophysical Union, Washington DC, pp. 303-332.

Knap, A., Michaels, A.F., Close, A., Ducklow, H.W., Dickson, A., 1994. Protocols for the Joint Global Ocean Flux Study (JGOFS) Core Measurements. UNESCO, Paris.

Lampitt, R.S., Antia, A.N., 1997. Particle flux in deep seas: regional characteristics and temporal variability. Deep Sea Research Part I: Oceanographic Research Papers 44 (8), 1377-1403.

Laws, E.A., Falkowski, P.G., Smith, W.O., Jr., Ducklow, H.W., McCarthy, J.J., 2000.

Temperature effects on export production in the open ocean. Global Biogeochemical Cycles 14, 1231-1246.

Liu, K.K., Iseki, K., Chao, S.-Y., 2000. Continental margin carbon fluxes. In: Hanson, R., Ducklow, H.W., Field, J.G. (Eds.), The Changing Ocean Carbon Cycle. Cambridge University Press, Cambridge, UK, pp. 187-239.

Martinson, D.G., Stammerjohn, S.E., Smith, R.C., Iannuzzi, R.A., 2008. Palmer, Antarctica, Long-Term Ecological Research program first 12 years: physical oceanography, spatio-temporal variability. Deep Sea Research II 55, 000-000. 
Montes-Hugo, M.A., Vernet, M., Smith, R.C., Carder, K., 2007. Phytoplankton size-structure on the western shelf of the Antarctic Peninsula: A remote sensing approach. International Journal of Remote Sensing 29, 801-829.

Povero, P., Misic, C., Ossola, C., Castellano, M., Fabiano, M., 2003. The trophic role and ecological implications of oval faecal pellets in Terra Nova Bay (Ross Sea). Polar Biology 26 (5), 302-310.

Probyn, T.A., Painting, S.J., 1985. Nitrogen Uptake by Size-Fractionated Phytoplankton Populations in Antarctic Surface Waters. Limnology and Oceanography 30, 1327-1332.

Robinson, A.R., Brink, K.H., Ducklow, H.W., Jahnke, R.A., Rothschild, B.J., 2004. Interdisciplinary Multiscale Coastal Dynamical Processes and Interactions. In: Robinson, A.R., Brink, K.H., Rothschild, B.J. (Eds.), The Sea. Harvard University Press, Cambridge. MA.

Ross, R.M., Hofmann, E.E., Quetin, L.B. (Eds.), 1996. Foundations for Ecological Research West of the Antarctic Peninsula.AGU Antarctic Research Series American Geophysical Union, Washington, DC.

Ross, R.M., Quetin, L.B., Martinson, D.G., Iannuzzi, R.J., Stammerjohn, S., Smith, R.C., 2008. Palmer LTER: Patterns of Distribution of Five Dominant Zooplankton Species in the Epipelagic Zone West of the Antarctic Peninsula, 1993 - 2004. Deep Sea Research II 55, 000-000.

Schlitzer, R., 2002. Carbon export fluxes in the Southern Ocean: results from inverse modeling and comparison with satellite-based estimates. Deep Sea Research Part II: Topical Studies in Oceanography 49 (9-10), 1623-1644.

Smith, C.R., Mincks, S., DeMaster, D.J., 2006. A synthesis of bentho-pelagic coupling on the Antarctic shelf: Food banks, ecosystem inertia and global climate change. Deep Sea Research Part II: Topical Studies in Oceanography 53 (8-10), 875-894.

Smith, C.R., Mincks, S., DeMaster, D.J., 2007. The FOODBANCS Project: Introduction and sinking fluxes of organic carbon, chlorophyll-a and phytodetritus on the western Antarctic Peninsula continental shelf. Deep Sea Research II 54, 000-000.

Smith, C.R., Mincks, S., DeMaster, D.J., 2008a. The FOODBANCS Project: Introduction and sinking fluxes of organic carbon, chlorophyll-a and phytodetritus on the western Antarctic Peninsula continental shelf. Deep Sea Research II 55, 000-000.

Smith Jr., W.O., Gordon, L.I., 1997. Hyperproductivity of the Ross Sea (Antarctica) polynya during austral spring. Geophysical Research Letters 24, 233-236.

Smith Jr., W.O., Marra, J., Hiscock, M.R., Barber, R.T., 2000. The seasonal cycle of phytoplankton biomass and primary productivity in the Ross Sea, Antarctica. Deep Sea Research Part II: Topical Studies in Oceanography 47 (15-16), 3119-3140.

Smith, R.C., Baker, K.S., Fraser, W.R., Hofmann, E.E., Karl, D.M., Klinck, J.M., Quetin, L.B., Prezelin, B.B., Ross, R.M., Trivelpiece, W.Z., Vernet, M., 1995. The Palmer LTER: A long-term ecological research program at Palmer Station, Antarctica. Oceanography 8 (3), 77-86.

Smith, R.C., Fraser, W.R., Stammerjohn, S.E., 2003a. Climate variability and ecological response of the marine ecosystem in the western Antarctic Peninsula (WAP) region In: Greenland, D., Goodin, D.G., Smith, R.C. (Eds.), Climate variability and ecosystem response at Long-Term Ecological Research Sites Oxford University Press, New York pp. 158-173. 
Smith, R.C., Fraser, W.R., Stammerjohn, S.E., Vernet, M., 2003b. Palmer Long-Term Ecological Research on the Antarctic Marine Ecosystem. In: Domack, E., Leventer, A., Burnett, A., Bindschadler, R., Convey, P., Kirby, M. (Eds.), Antarctic Peninsula Climate Variability: Historical and Paleoenvironmental Perspective. American Geophysical Union, Washington, DC, pp. 131-144.

Smith, R.C., Martinson, D.G., Stammerjohn, S.E., Iannuzzi, R.A., Ireson, K., 2008 b. Bellingshausen and Western Antarctic Peninsula Region: Pigment biomass and sea ice spatial/temporal distributions and interannual variability. Deep Sea Research II 55, 000-000.

Smith, S.V., Hollibaugh, J.T., 1993. Coastal metabolism and the oceanic organic carbon balance. Reviews of Geophysics 31 (1), 75-89.

Stammerjohn, S.E., Martinson, D.G., Smith, R.C., Iannuzzi, R.A., 2008. Sea Ice in the Western Antarctic Peninsula Region: Spatio-Temporal Variability from Ecological and Climate Change Perspectives. Deep Sea Research II 55, 000-000.

Takahashi, T., Sutherland, S.C., Sweeney, C., Poisson, A., Metzl, N., Tilbrook, B., Bates, N., Wanninkhof, R., Feely, R.A., Sabine, C., Olafsson, J., Nojiri, Y., 2002. Global sea-air CO2 flux based on climatological surface ocean $\mathrm{pCO}$, and seasonal biological and temperature effects. Deep-Sea Research II 49, 1601-1622.

Tsunogai, S., Watanabe, S., Sato, T., 1999. Is there a "continental shelf pump" for the absorption of atmospheric CO2? Tellus. Series B: Chemical and Physical Meteorology 51B, 701-712.

Turner, J.T., 2002. Zooplankton fecal pellets, marine snow and sinking phytoplankton blooms. Aquatic Microbial Ecology 27, 57-102.

Vaughan, D.G., Marshall, G.J., Connolley, W.M., Parkinson, C., Mulvaney, R., Hodgson, D.A., King, J.C., Pudsey, C.J., Turner, J., 2003. Recent rapid regional climate warming on the Antarctic Peninsula. Climatic Change 60, 243-274.

Vernet, M., Martinson, D.G., Iannuzzi, R.A., Stammerjohn, S.E., Kozlowski, W.A., Sines, K., Smith, R.C., 2007. Control of Primary Production by Sea Ice Dynamics in the Western Antarctic Peninsula. Deep Sea Research II (submitted).

Vernet, M., Martinson, D.G., Iannuzzi, R.A., Stammerjohn, S.E., Kozlowski, W., Sines, K., Smith, R.C., Garibotti, I., 2008. Primary Production within the Sea Ice Zone west of the Antarctic Peninsula. Deep Sea Research II 55, 000-000.

Walsh, J.J., Rowe, G.T., Iverson, R.L., McRoy, C.P., 1981. Biological export of shelf carbon is a neglected sink of the global CO2 cycle. Nature 291, 196-201.

Walsh, J.J., 1988. On the nature of continental shelves. Academic Press, San Diego.

Waters, K.J., Smith, R.C., 1992. Palmer LTER: A sampling grid for the Palmer LTER program. Antarctic Journal of the United States 27 (5), 236-239.

Wefer, G., Fischer, G., Futterer, D., Gersonde, R., 1988. Seasonal particle flux in the Bransfield Strait, Antarctica. Deep-Sea Research 35, 891-898.

Yager, P.L., Wallace, D.W.R., Johnson, K.M., Smith, W.O., Jr., Minnett, P.J., Deming, J.W., 1995. The Northeast Water Polynya as an atmospheric CO2 sink: A seasonal rectification hypothesis. Journal of Geophysical Research. C. Oceans 100 (C3), 4389-4398. 
Table 1. Details of time-series of PAL-LTER sediment trap deployments, 1992-2006.

\begin{tabular}{|c|c|c|c|c|c|c|}
\hline Deployment & Trap & $\begin{array}{c}\text { Location } \\
\text { (Lat S; Long W) }\end{array}$ & Depth & Start date & End date & amples \\
\hline $1 \mathrm{~A}$ & 1 & 6430.206601 .7 & 350 & 7-Nov-92 & 11-Dec-92 & 5 \\
\hline 1B & 2 & 6443.706611 .0 & 350 & 7-Nov-92 & 28-Mar-93 & 21 \\
\hline $1 \mathrm{C}$ & 3 & 6444.106551 .2 & 350 & 7-Nov-92 & 4-Dec-92 & 4 \\
\hline $2 \mathrm{~A}$ & 1 & $6430.22 \quad 06601.7$ & 350 & 15-Apr-93 & 14-Jan-94 & 21 \\
\hline $2 \mathrm{~B}$ & 2 & 6443.7506611 .0 & 350 & 15-Apr-93 & 14-Jan-94 & 21 \\
\hline $2 \mathrm{C}$ & 3 & $6430.22 \quad 06601.71$ & 350 & 15-Apr-93 & 14-Jan-94 & 21 \\
\hline $3 \mathrm{~A}$ & 1 & 6429.4906559 .14 & 350 & 28-Jan-94 & 7-Dec-94 & 21 \\
\hline $3 C^{1}$ & 3 & 6610.0506625 .17 & 352 & 30-Jan-94 & 7-Dec-94 & 21 \\
\hline $4 \mathrm{~A}$ & 1 & 6429.8506602 .54 & 350 & 18-Dec-94 & 15-Dec-95 & 18 \\
\hline $4 \mathrm{C}$ & 3 & 6429.8506602 .54 & 350 & 18-Dec-94 & 15-Dec-95 & 18 \\
\hline $5 \mathrm{~A}$ & 1 & 6430.3206604 .75 & 350 & 16-Dec-95 & 25-Mar-96 & 9 \\
\hline $5 D^{2}$ & 4 & 6450.1106408 .36 & 519 & 16-Dec-95 & 25-Dec-96 & 18 \\
\hline 6 & 1 & 6430.2006603 .36 & 350 & 27-Dec-96 & 8-Jan-98 & 21 \\
\hline 7 & 1 & 6429.3006602 .48 & 350 & 1-Feb-98 & 27-Dec-98 & 20 \\
\hline 8 & 1 & 6429.2606602 .97 & 350 & 26-Jan-99 & 6-Dec-99 & 17 \\
\hline 9 & 1 & 6428.906602 .5 & 350 & 8-Dec-99 & 30-Dec-00 & 20 \\
\hline 10 & 1 & & 350 & \multicolumn{3}{|c|}{ Trap malfunction } \\
\hline 11 & 1 & 6429.0606602 .62 & 350 & 20-Jan-02 & 20-Jan-03 & 19 \\
\hline 12 & 2 & 6429.1206602 .03 & 350 & 20-Jan-03 & 10-Jan-04 & 21 \\
\hline 13 & 1 & 6428.8806602 .45 & 350 & 20-Jan-04 & 15-Jan-05 & 21 \\
\hline 14 & 2 & 6428.9406602 .54 & 350 & 20-Jan-05 & 10-Jan-06 & 21 \\
\hline 15 & 1 & 6428.9706602 .59 & 350 & 20-Jan-06 & 11-Jan-07 & 21 \\
\hline
\end{tabular}

${ }^{1}$ Trap moored in Crystal Sound, $197 \mathrm{~km}$ from main mooring near Hugo Island.

${ }^{2}$ Trap moored in Palmer Basin 97 km from main mooring near Hugo Island. 
Table 2. Vertical sedimentation fluxes of carbon, nitrogen and phosphorus at 170 meters depth on the continental shelf of the west Antarctic Peninsula, 1993-2006.

\begin{tabular}{|c|c|c|c|c|c|c|}
\hline Calendar & C flux & N flux & P flux & $\mathrm{C}: \mathbf{N}$ & $\mathbf{N}: \mathbf{P}$ & $\mathrm{C}: \mathbf{P}$ \\
\hline Year & \multicolumn{3}{|c|}{------ mmol m² $\mathrm{a}^{-1}$------ } & \multicolumn{3}{|c|}{---------- ratios --------- } \\
\hline 1993 & 151 & 19.3 & 1.06 & 7.8 & 18.3 & 143 \\
\hline 1994 & 140 & 16.5 & 1.06 & 8.5 & 15.6 & 132 \\
\hline 1995 & 343 & 41.0 & 1.53 & 8.4 & 26.8 & 224 \\
\hline 1996 & 216 & 26.2 & 1.46 & 8.2 & 18.0 & 148 \\
\hline 1997 & 13 & 1.8 & 0.03 & 7.1 & 67.0 & 474 \\
\hline 1998 & 280 & 33.3 & 1.02 & 8.4 & 32.5 & 274 \\
\hline 1999 & 344 & 42.8 & 1.35 & 8.0 & 31.8 & 256 \\
\hline 2000 & 246 & 31.6 & 1.23 & 7.8 & 25.6 & 200 \\
\hline 2002 & 163 & 17.6 & 0.64 & 9.2 & 27.5 & 254 \\
\hline 2003 & 182 & 23.3 & 1.22 & 7.8 & 19.1 & 149 \\
\hline 2004 & 168 & 19.3 & 0.10 & 8.7 & 191.3 & 1661 \\
\hline 2005 & 101 & 13.1 & -- & 7.7 & -- & -- \\
\hline 2006 & 413 & 45.4 & -- & 9.1 & -- & -- \\
\hline Average & 212 & 25 & 1 & 8.2 & $28.2^{*}$ & $225 *$ \\
\hline Std Err & 31 & 3.6 & 0.15 & 0.16 & 4.7 & 32.3 \\
\hline
\end{tabular}

*averages do not include the 2004 values 
Table 3. Dates and duration of annual flux peak and its contribution to total annual sedimentation flux (no peak data for 200001 and 2001-02 seasons due to trap failure in 2001-02). See also Supplementary materials. The annual totals in this table were calculated from the start of one peak to the start of the next peak (annual totals in Table 2 are calendar-year totals).

\begin{tabular}{|c|c|c|c|c|c|c|c|c|}
\hline Season & $\begin{array}{c}\text { Peak Start } \\
\text { Date }\end{array}$ & $\begin{array}{c}\text { Date of peak } \\
\text { maximum }\end{array}$ & $\begin{array}{l}\text { Peak End } \\
\text { Date }\end{array}$ & $\begin{array}{l}\text { Duration } \\
\text { (days) }\end{array}$ & $\begin{array}{l}\text { Flux in peak } \\
\left(\mathrm{mmolC} \mathrm{m}^{-2}\right)\end{array}$ & 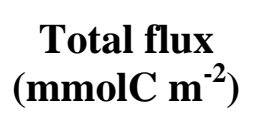 & $\begin{array}{c}\text { Fraction in } \\
\text { peak }\end{array}$ & $\begin{array}{c}\text { Flux Stability } \\
\text { Index (days) }\end{array}$ \\
\hline $92-93$ & 7-Nov & 14-Dec & 15-Jun & 220 & 252 & 276 & 0.92 & 40 \\
\hline $93-94$ & 14-Jan & 31-Jan & 25-Mar & 71 & 71 & 95 & 0.75 & 41 \\
\hline $94-95$ & 7-Dec & 11-Jan & 15-Mar & 98 & 278 & 351 & 0.79 & 28 \\
\hline $95-96$ & 16-Dec & 19-Dec & 25-Mar & 99 & 170 & 217 & 0.78 & 58 \\
\hline $96-97$ & 27-Nov & 30-Dec & 10-Jan & 44 & 39 & 55 & 0.70 & 25 \\
\hline Avg & 8-Dec & 3-Jan & 25-Mar & 106 & 162 & 199 & 0.79 & 38 \\
\hline $97-98$ & 8-Jan & 18-Feb & 1-May & 114 & 230 & 282 & 0.81 & 48 \\
\hline $98-99$ & 26-Jan & 16-Mar & 1-Jun & 142 & 194 & 230 & 0.84 & 69 \\
\hline $99-00$ & 8-Dec & 12-Feb & 1-Apr & 114 & 238 & -- & -- & 56 \\
\hline 00-01 & -- & -- & -- & -- & -- & -- & -- & -- \\
\hline 01-02 & -- & 13-Feb & 15-Mar & -- & -- & -- & -- & -- \\
\hline 02-03 & 20-Jan & 30-Jan & 1-Jun & 133 & 121 & 147 & 0.82 & 40 \\
\hline 03-04 & 20-Jan & 16-Feb & 1-Jun & 133 & 121 & 150 & 0.80 & 53 \\
\hline 04-05 & 20-Jan & 23-Jan & 3-Feb & 14 & 15 & 86 & 0.18 & 156 \\
\hline $05-06$ & 03-Jan & 20-Feb & 01-Apr & 90 & 340 & 350 & 0.97 & 45 \\
\hline Avg & 08-Jan & 14-Feb & 23 Apr & 106 & 180 & 208 & 0.87 & 66 \\
\hline $\begin{array}{c}\text { Overall } \\
\text { Avg }\end{array}$ & 26 Dec & 29 Jan & 11 April & 106 & 172 & 204 & 0.85 & 55 \\
\hline
\end{tabular}


Table 4. Time-integrated primary production ${ }^{1}$, sedimentation ${ }^{2}$ and sedimentation to production ratio in the Austral summer at the Palmer LTER sediment trap site, 1997 - 2006.

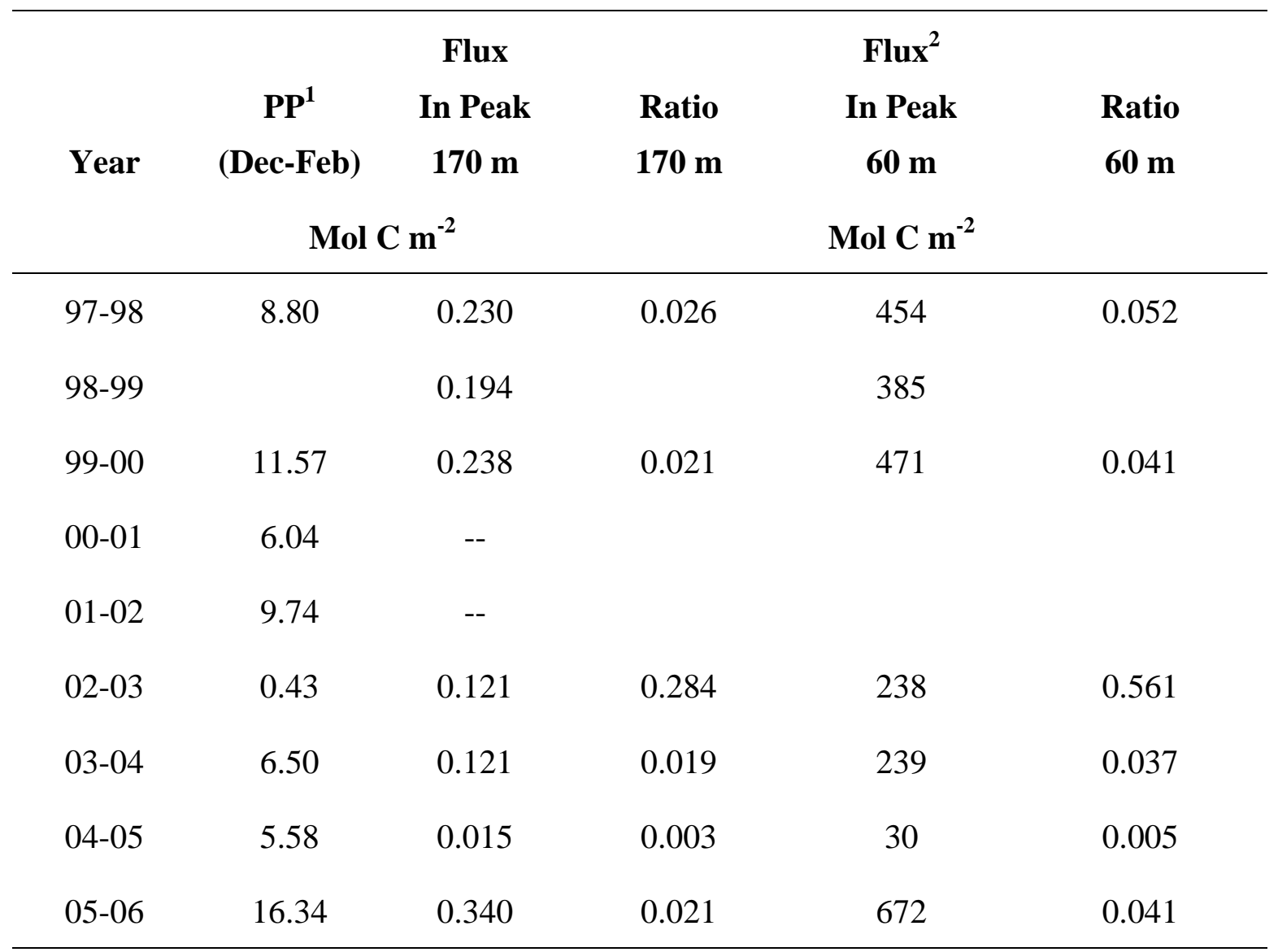

${ }^{1} \mathrm{PP}$ from SeaWiFS-based estimates for the sediment trap site; see Methods for details.

${ }^{2}$ fluxes at 60 meters were scaled using the Martin et al (1987) equation $F_{60}=F_{170}(60 / 170)^{-0.66}$ with the exponent -0.655 calculated from RACER data (Karl et al. 1991b; see Discussion). 
Table 5. Annual sedimentation flux for selected sites. See also Figure 10.

Location, year and trap depth $\quad$ Flux $\left(\mathrm{mmolC} \mathrm{m}^{-2} \mathrm{a}^{-1}\right) \quad$ Reference

\begin{tabular}{lcl}
\hline WAP mean flux, 1993-2006, 170 m & 212 & This study \\
WAP flux, 1997, 170 m & 13 & This study \\
Ross Sea, 1996-98, $206 \mathrm{~m}$ & 396 & Honjo et al. (2000) \\
Bransfield Strait, 1983-84, 494 m* & 48 & Wefer et al. (1988) \\
Weddell Sea, 1985, 863 m* & 0.1 & Fischer et al. (1988) \\
Bermuda (BATS), 1988-97, 150 m & 780 & Steinberg et al. (2001) \\
\hline
\end{tabular}

*scaled to 150 m using $\mathrm{F}_{\mathrm{Z}}=\mathrm{F}_{100}(\mathrm{z} / 100)^{\mathrm{b}}$ (Martin et al. 1987) and POC $=5 \%$ of total mass. 
Table 6. Comparison of POC fluxes at FOODBANCS and Palmer LTER sites of Western Antarctic Peninsula. (na - missing record).

\begin{tabular}{lccc} 
Dates* & FOODBANCS & LTER 1999-2000 & LTER 1993-2005 \\
\hline Dec 99 - March 00 & 21.96 & 31.15 & 17.84 \\
March 00 - June 00 & 21.00 & 2.97 & 5.38 \\
June 00 - Oct 00 & 5.04 & 1.59 & 0.93 \\
Nov 00 - March 01 & 56.04 & na & 14.04 \\
\hline
\end{tabular}

* Dates of FOODBANCS trap deployment and corresponding averaging periods for LTER collections. 


\section{Figure Legends.}

Figure 1. Map of Palmer LTER study region showing sediment trap location (white circle offshore) and Palmer Station (white circle to right) on Anvers Island. Bathymetry indicated by colored shading and color bar. Black dots are LTER hydrographic stations on grid lines 200 (south) to 600 (north).

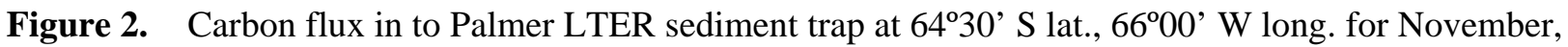
1992 to December, 1997 showing variability in results from multiple trap deployments (symbols) and the mean flux calculated from the trap catches (solid line). Numbers at top of panel indicate individual trap deployments. Vertical gray bars indicate gaps in the deployments (7-30 d). See also Table 1 and Supplemental Materials.

Figure 3. A. Black shading: Total dry mass flux into sediment traps, $1992-2007$. Gray shading: sea ice coverage over the trap mooring. B: Black bars: \% organic carbon in the total mass flux.

Figure 4. A. Mean carbon flux into Palmer LTER sediment trap, Nov. 1992 - Jan. 2007. Dashed line: surface chlorophyll concentration over the trap location (monthly average from SeaWiFS and see Smith et al. 2008). B. Mean nitrogen flux (black shading). C. Mean phosphorus flux into the traps. Note that in 1997 the fluxes were very low whereas in 2001 there were no data due to a trap failure.

Figure 5. Annual carbon fluxes integrated for each calendar year (January to January, black bars) and from midwinter to midwinter (July to July, gray bars). A trap failure in 2001 prevented integration of the 2002 July to July flux as well as the 2001 fluxes. See Table 2.

Figure 6. Date of occurrence of annual flux maxima ("peaks”) and their time-integrated carbon fluxes. The numbers above the bars are the ending years of the peak season as defined in Table 3

Figure 7. Carbon fluxes (as in Figure 3) plotted against mass fluxes (as in Figure 2) showing that carbon flux is proportionally lower at high mass flux, indicating lower organic content when fluxes are dominated by ice-rafted lithogenic materials.

Figure 8. Elemental ratios of discrete trap samples. A. C:N ratios. B. C:P ratios. C. N:P ratios. In each panel the lines show the linear regressions with the slope values defining the mean ratios for the entire data set. Slopes were all significant and y-intercepts were not significantly different from zero.

Figure 9. Temporal variability in carbon flux and elemental ratios. A. carbon flux as in Figure 3, but plotted as the $\log _{10}$ flux to emphasize the low fluxes. The solid line shows a flux of $0.22 \mathrm{mmolC}$ $\mathrm{m}^{-2} \mathrm{~d}^{-1}$ indicating the threshold for peak vs nonpeak fluxes. B: C:N ratios. C. N:P ratios. D. C:P ratios. In panels B,C,D the dashed lines show the canonical Redfield ratios and the dotted lines indicate the arithmetic means for each ratio. The dotted vertical lines in each panel are aligned with the peak fluxes in panel $\mathrm{A}$, to facilitate comparison of the phasing of peaks in elemental ratios with peak flux period.

Figure 10. Annual cycles of sedimentation in Antarctic shelf seas. The Ross Sea data are from the US JGOFS Southern Ocean study, as originally described in (Collier et al., 2000). The Bransfield Strait data were estimated from mass flux data given in Wefer et al. (1988) using their mean organic matter and carbon contents. For additional comparison, BATS data for the monthly mean flux were calculated with data obtained from the US JGOFS data archive (see Methods), as originally published in (Steinberg et al., 2001). Standard error bars on the WAP and BATS series are within the symbols. 
Figure 1

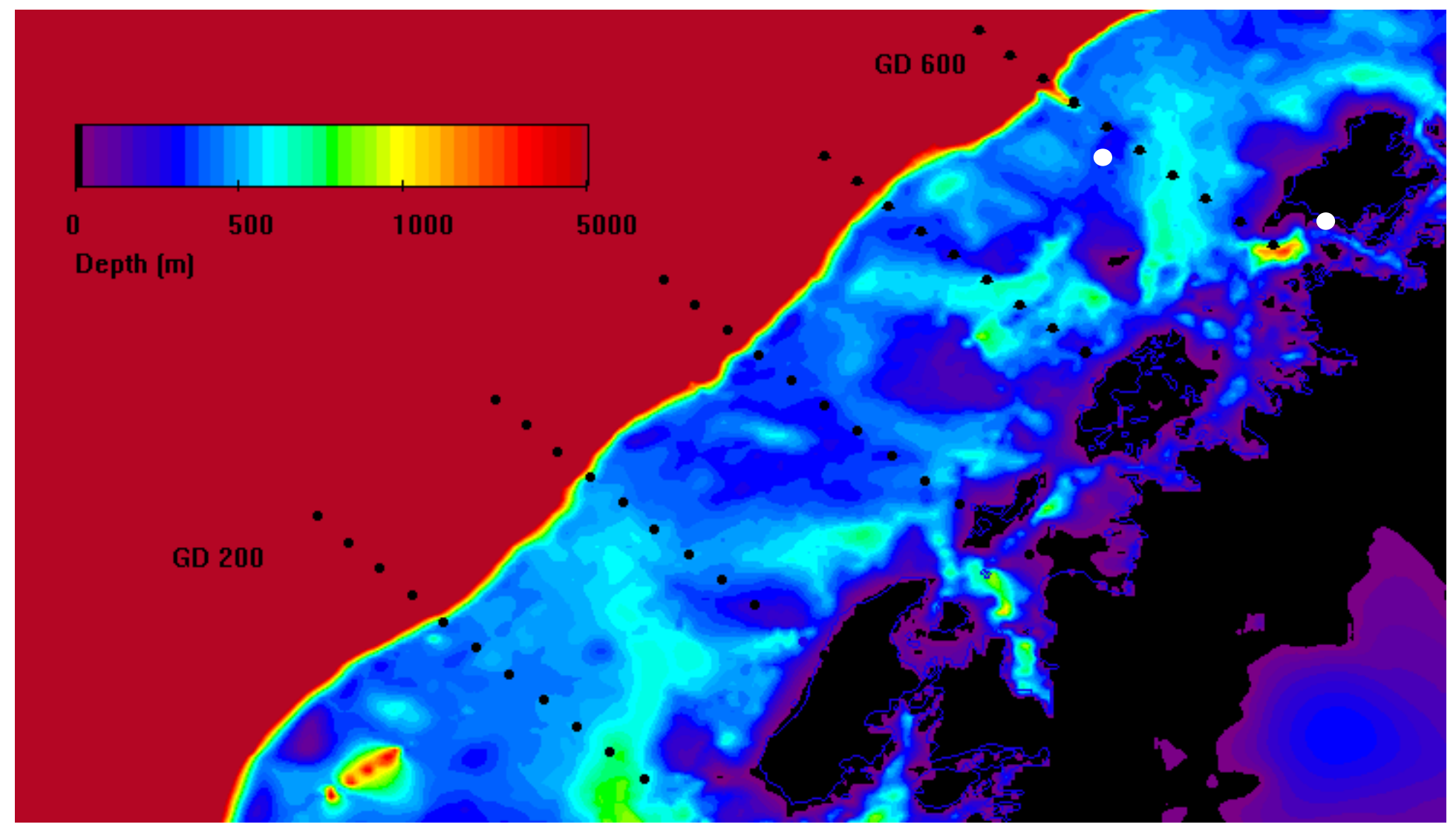


FIGURE 2

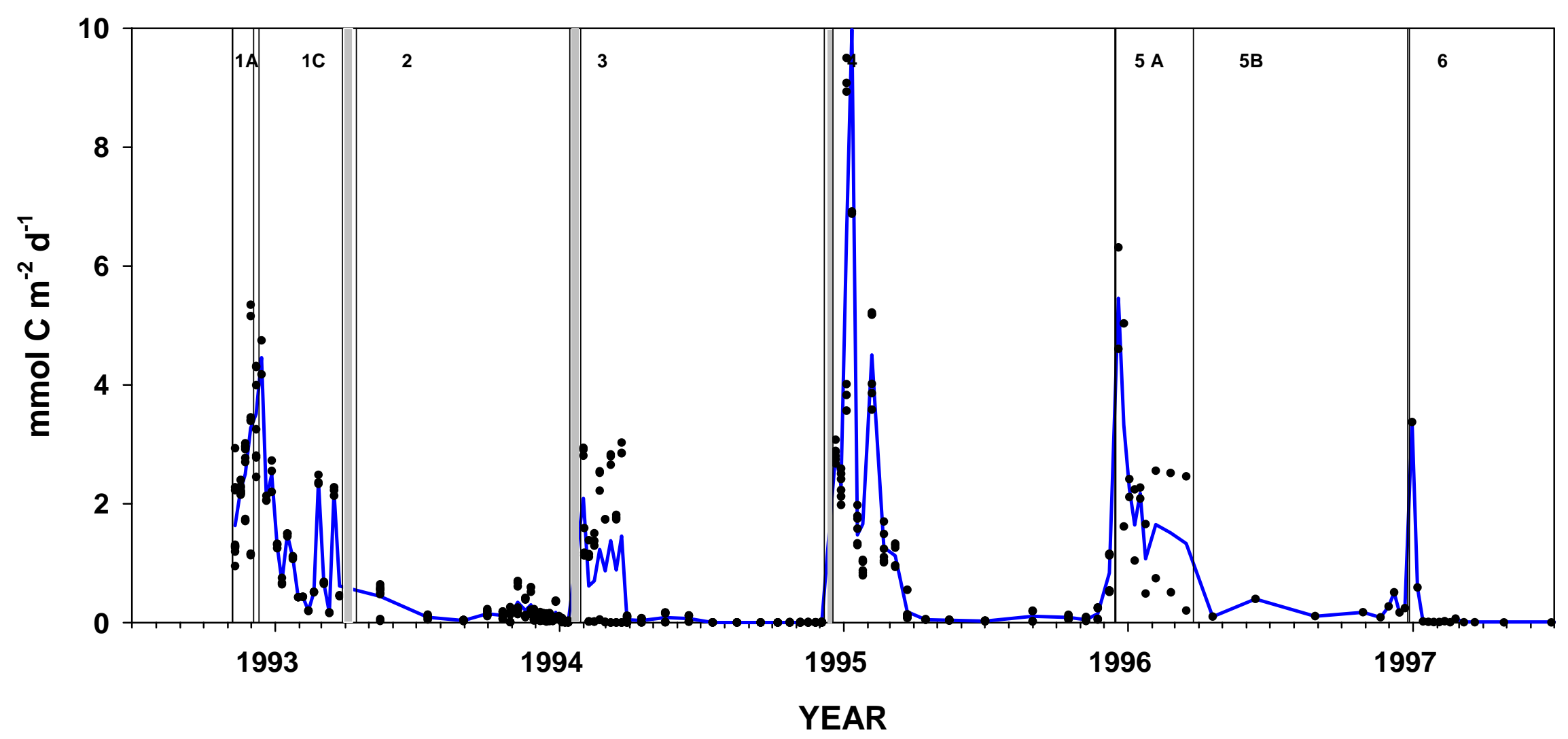


Figure 3

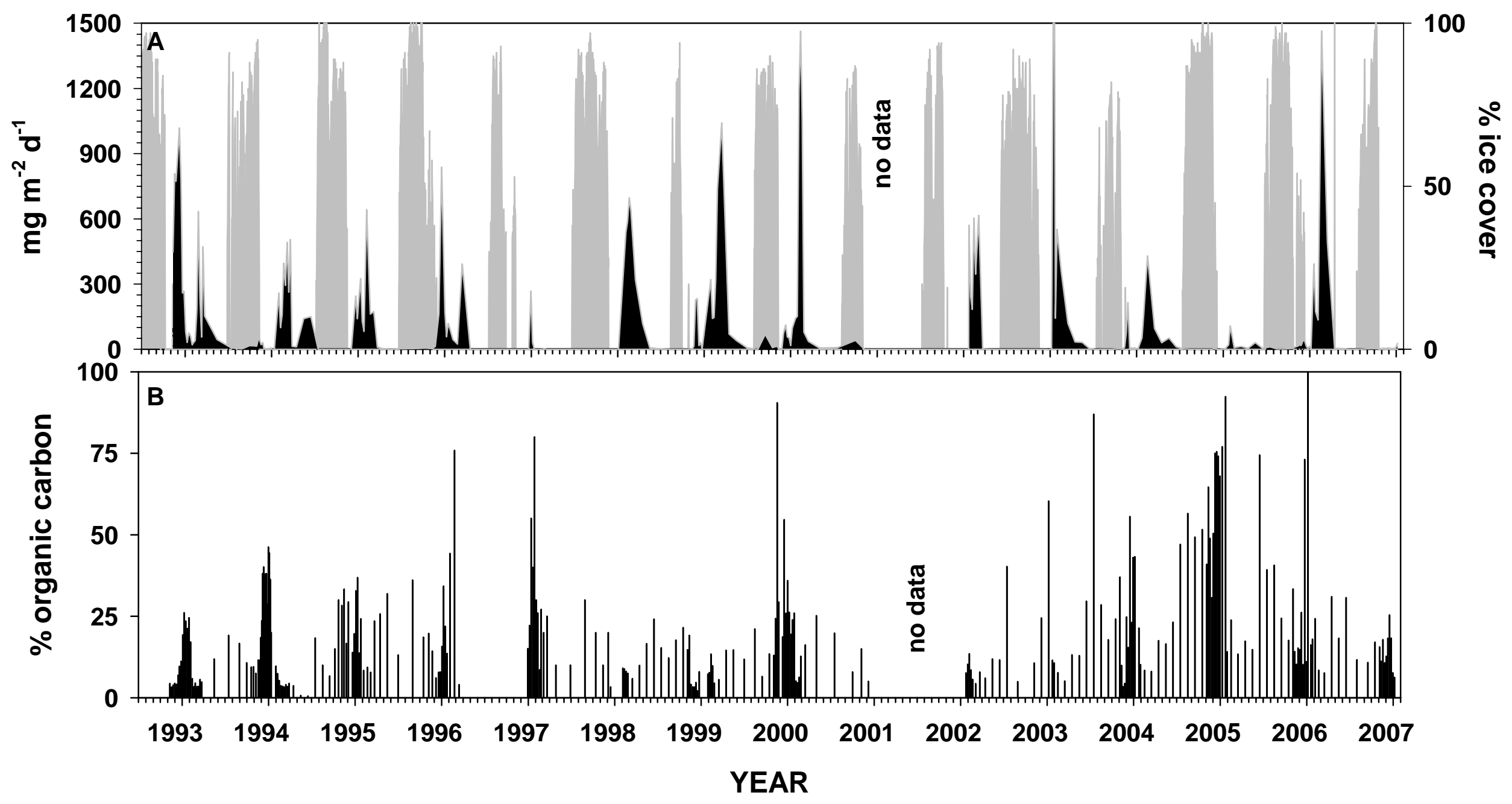


FIGURE 4
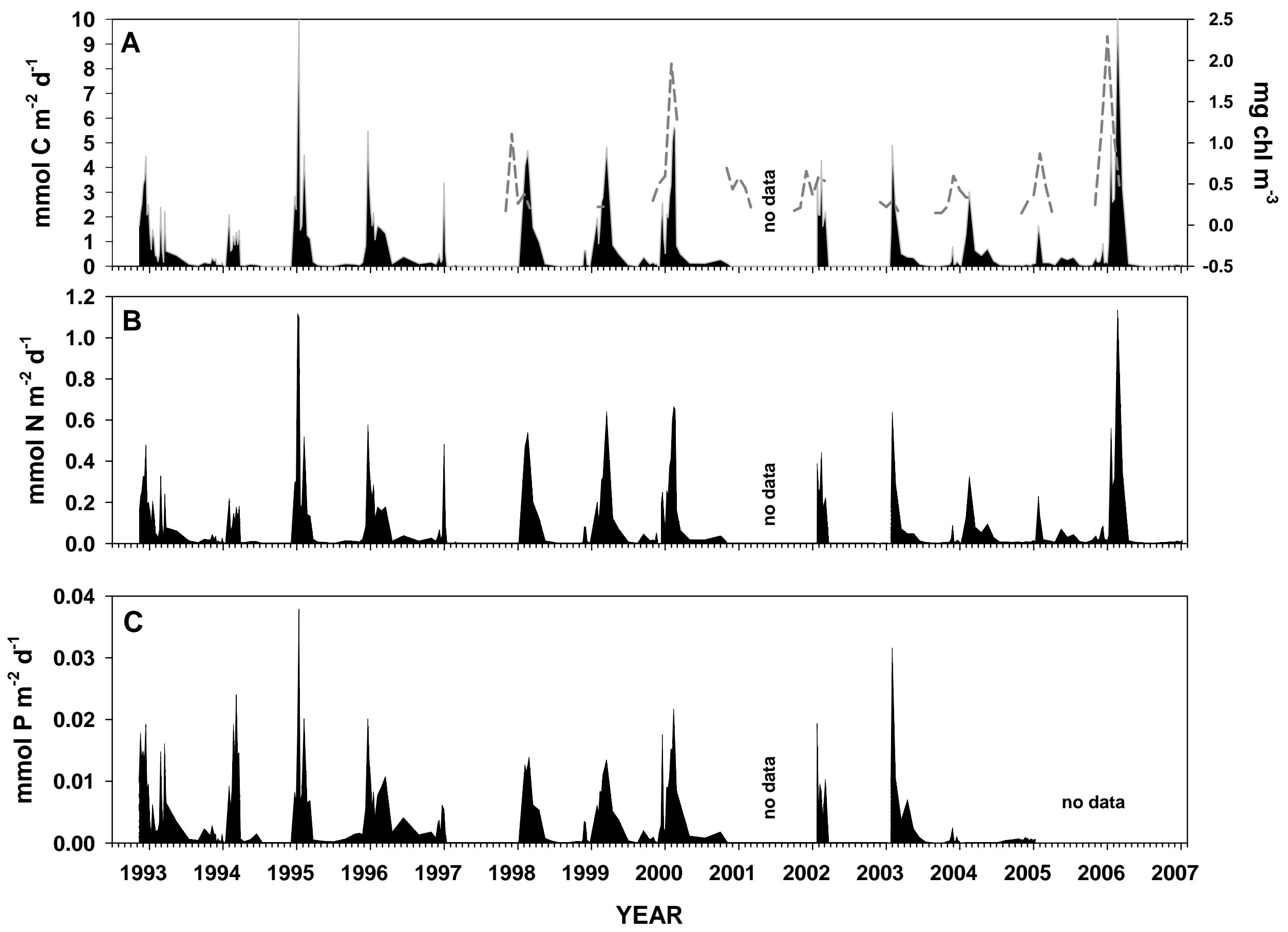


\section{FIGURE 5}

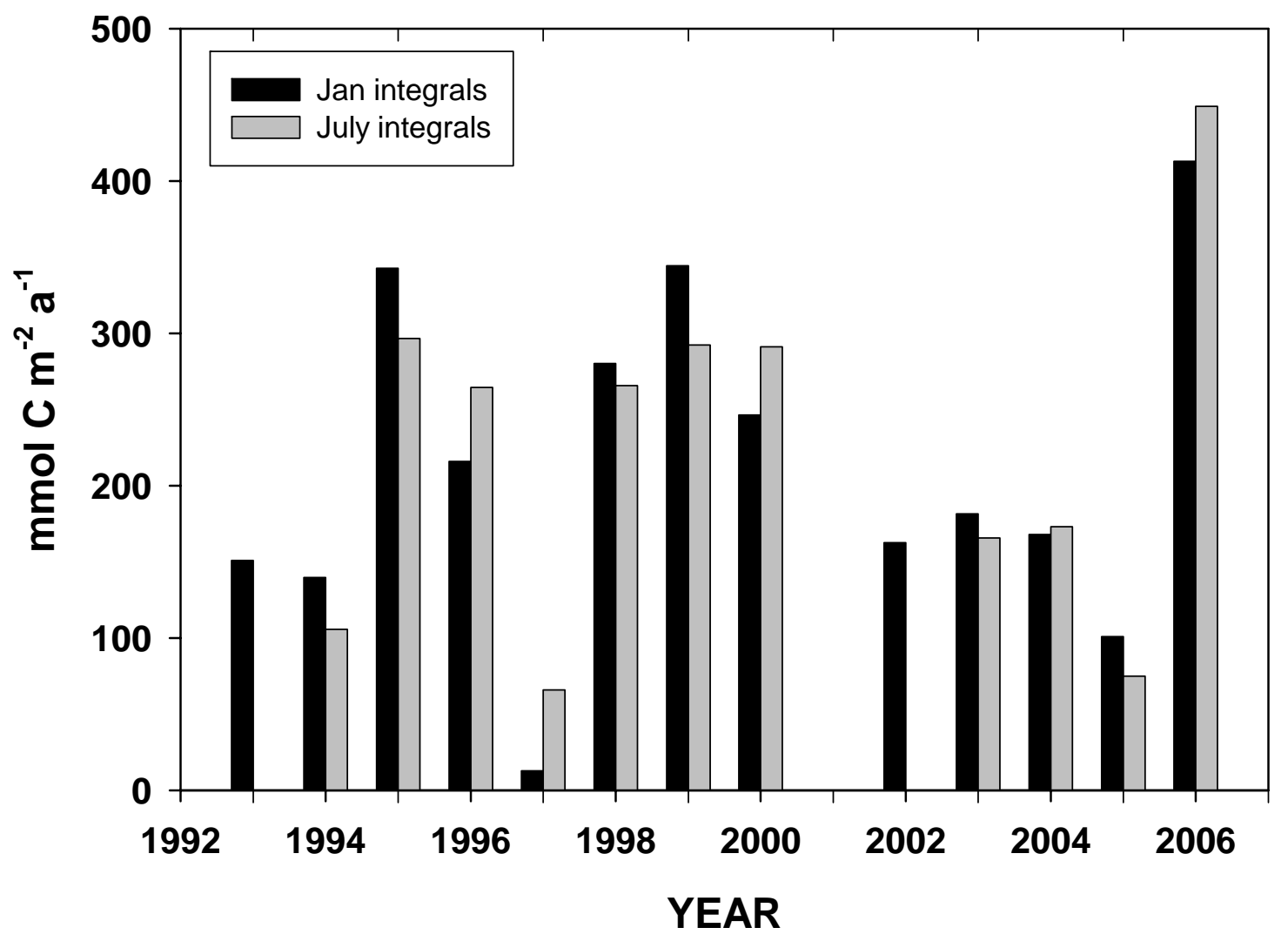


Figure 6

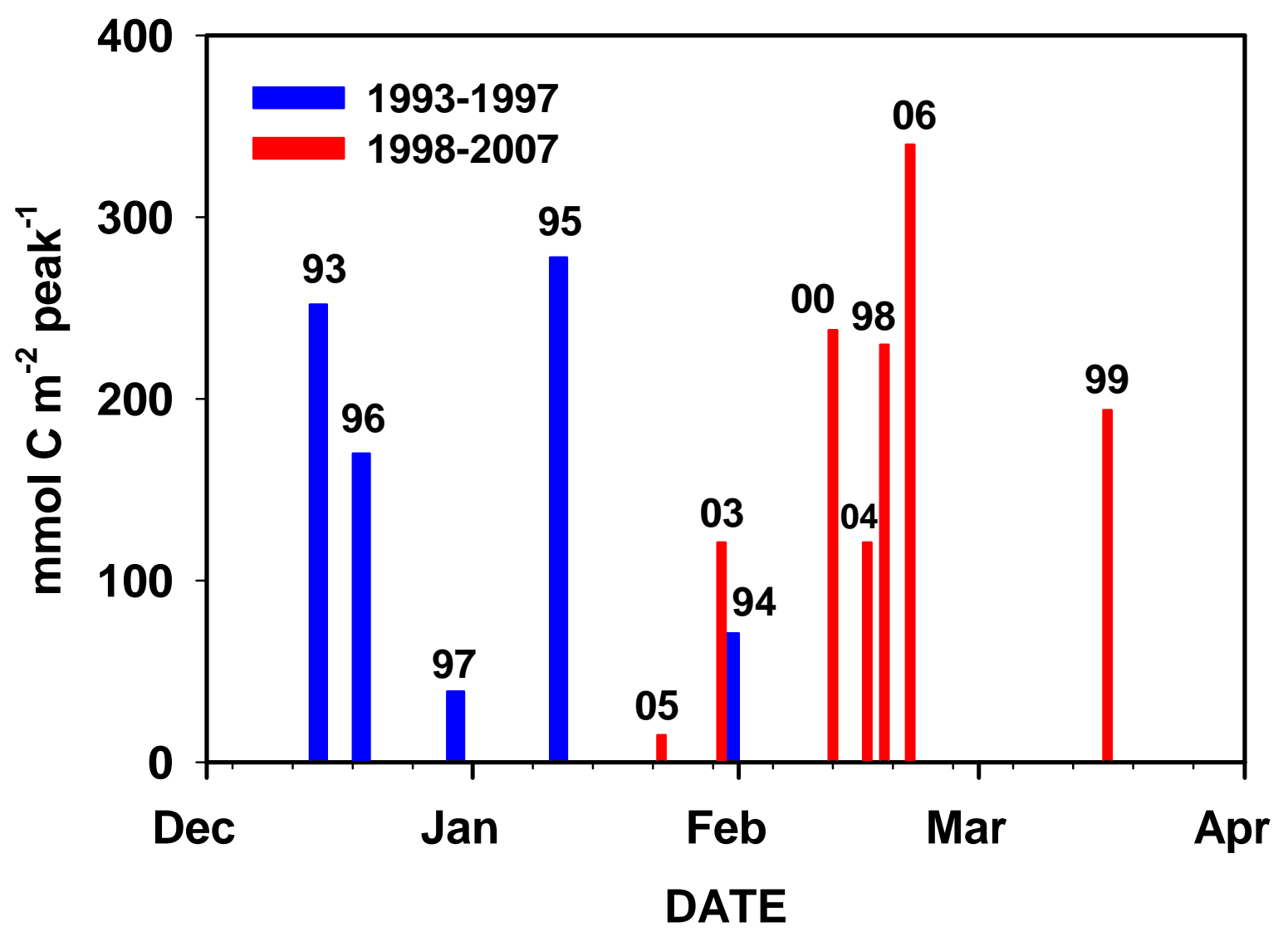


Figure 7

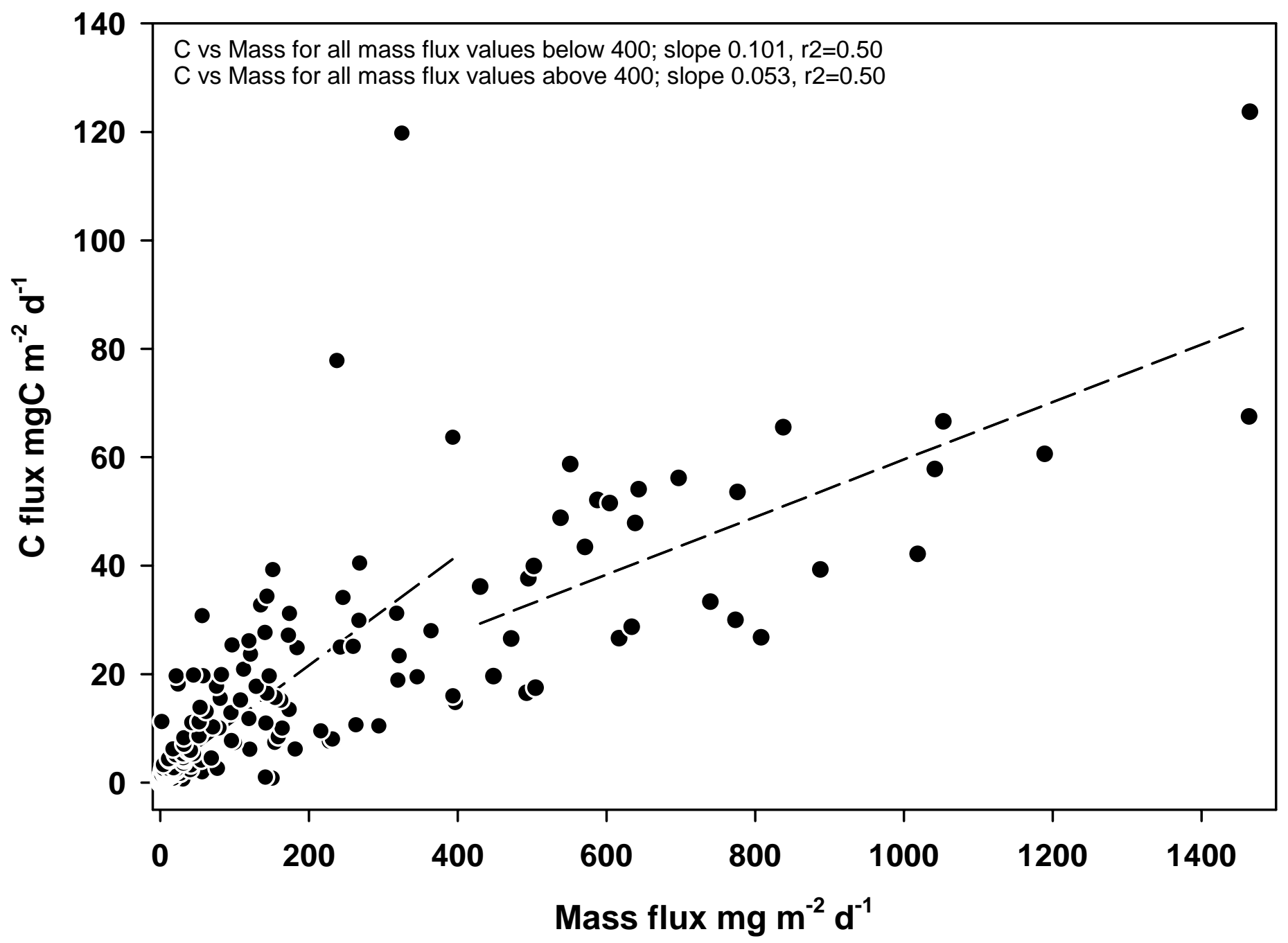


FIGURE 8
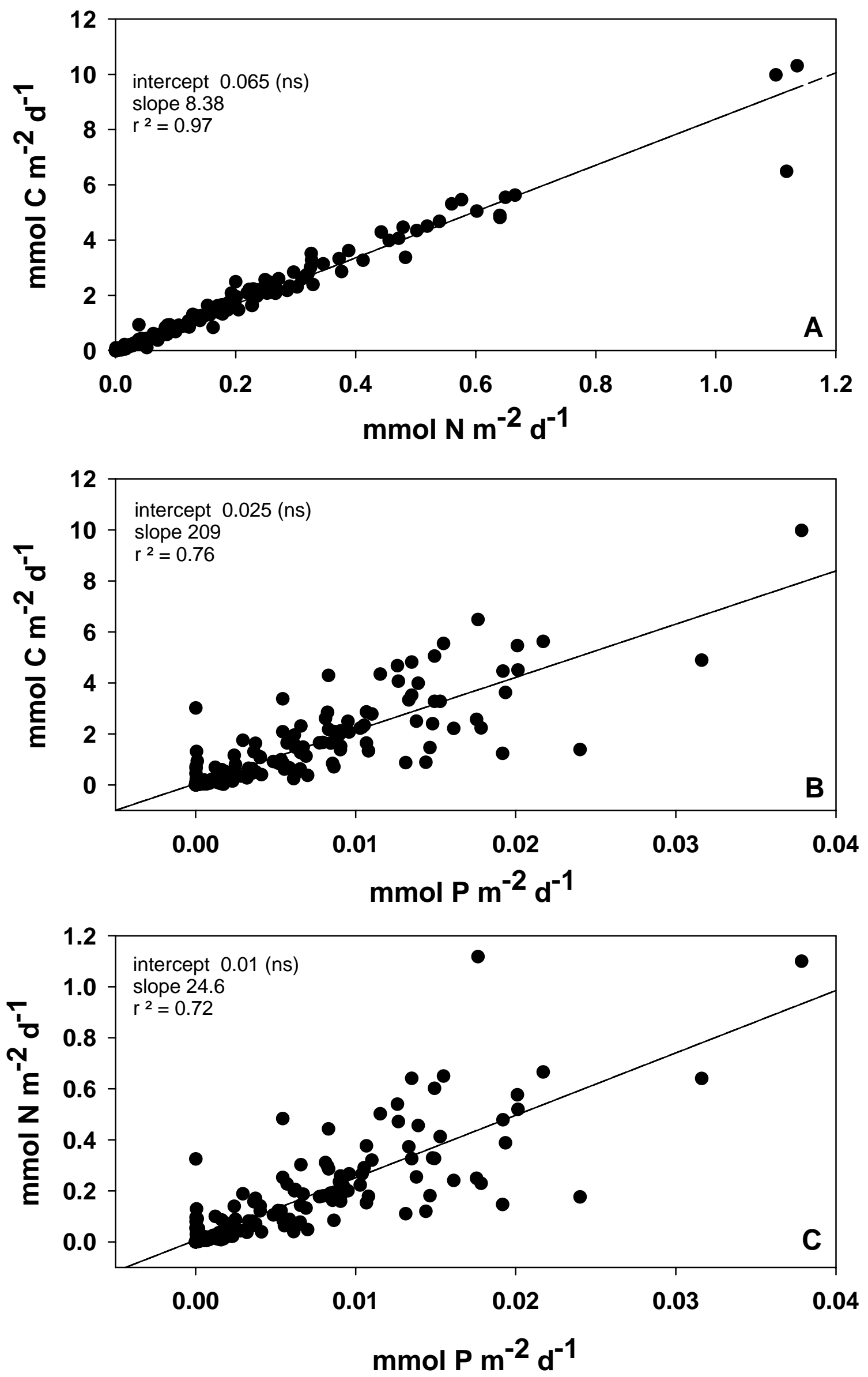
FIGURE 9
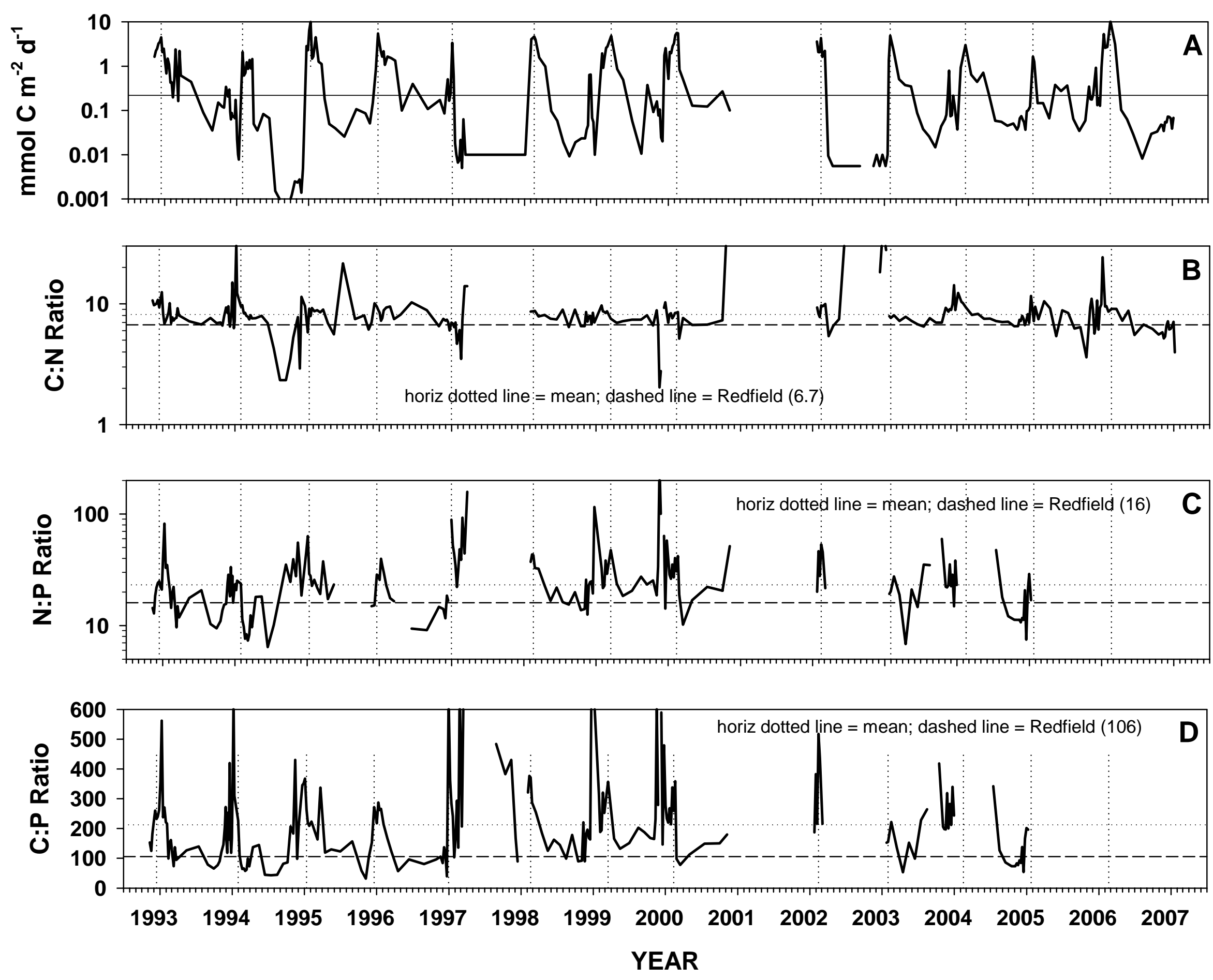
FIGURE 10

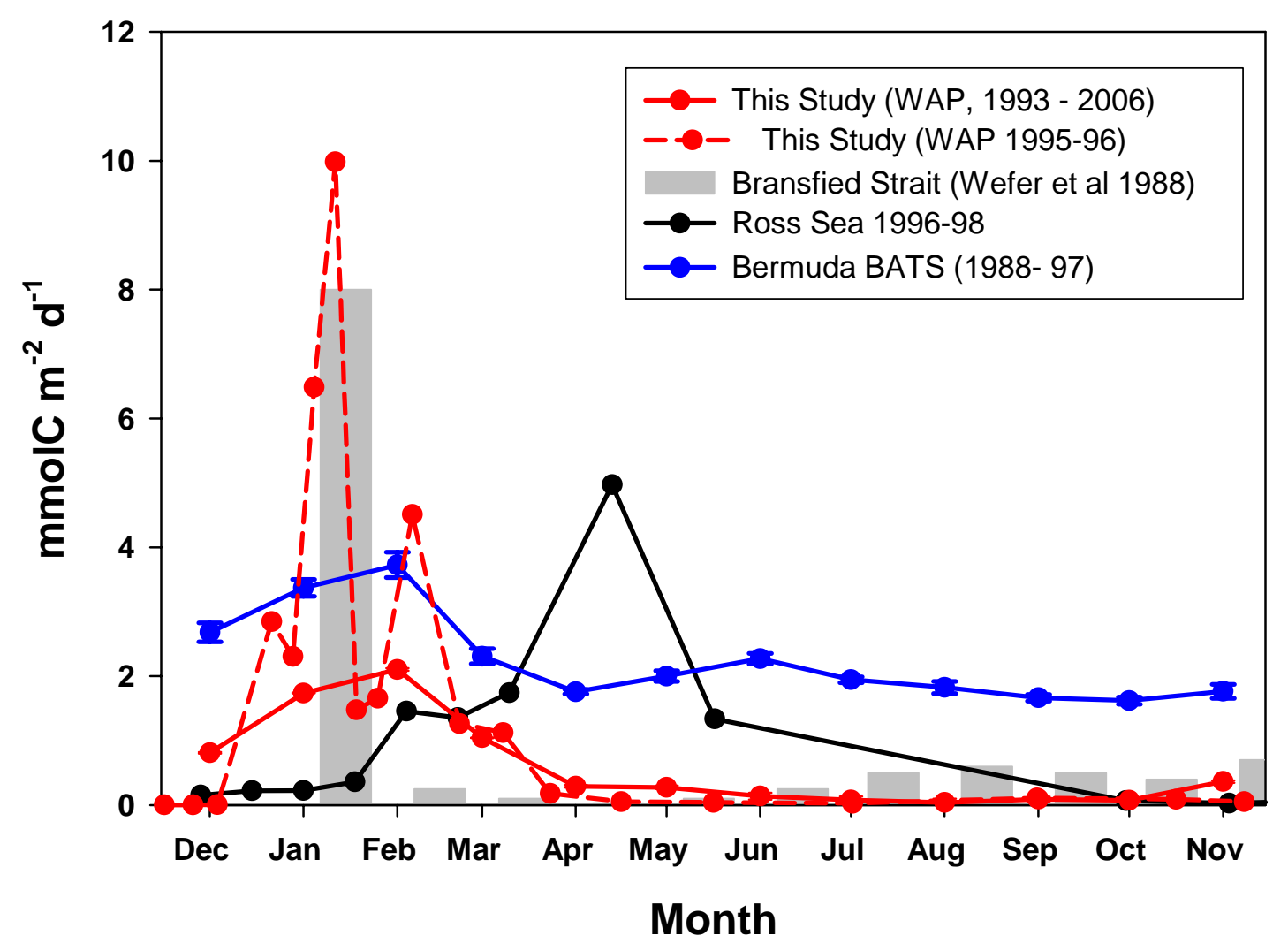


Supplemental materials for "Particle export from the upper ocean over the continental shelf of the west Antarctic Peninsula: A long-term record, 1992-2007,” by Ducklow et al.

1. Graphs showing carbon fluxes captured in multiple trap deployments. See Table 1 in main text for details of these deployments.

2. Statistical analysis of the differences in sedimentation peak occurrence between 1993 2007. See Table 3 and Figure 5 in main text. 
Deployment 2 1993-1994

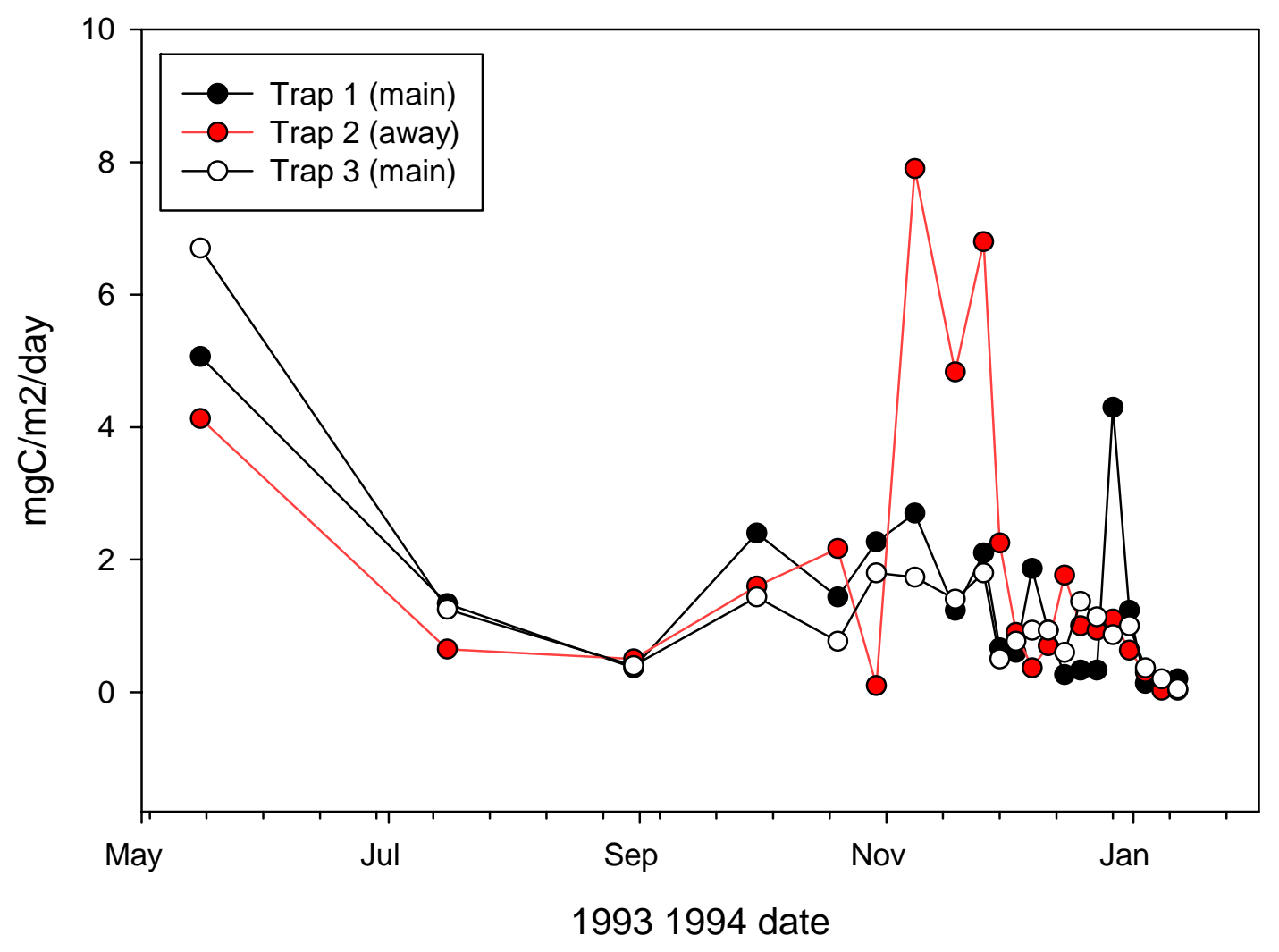


Deployment 3 a,c

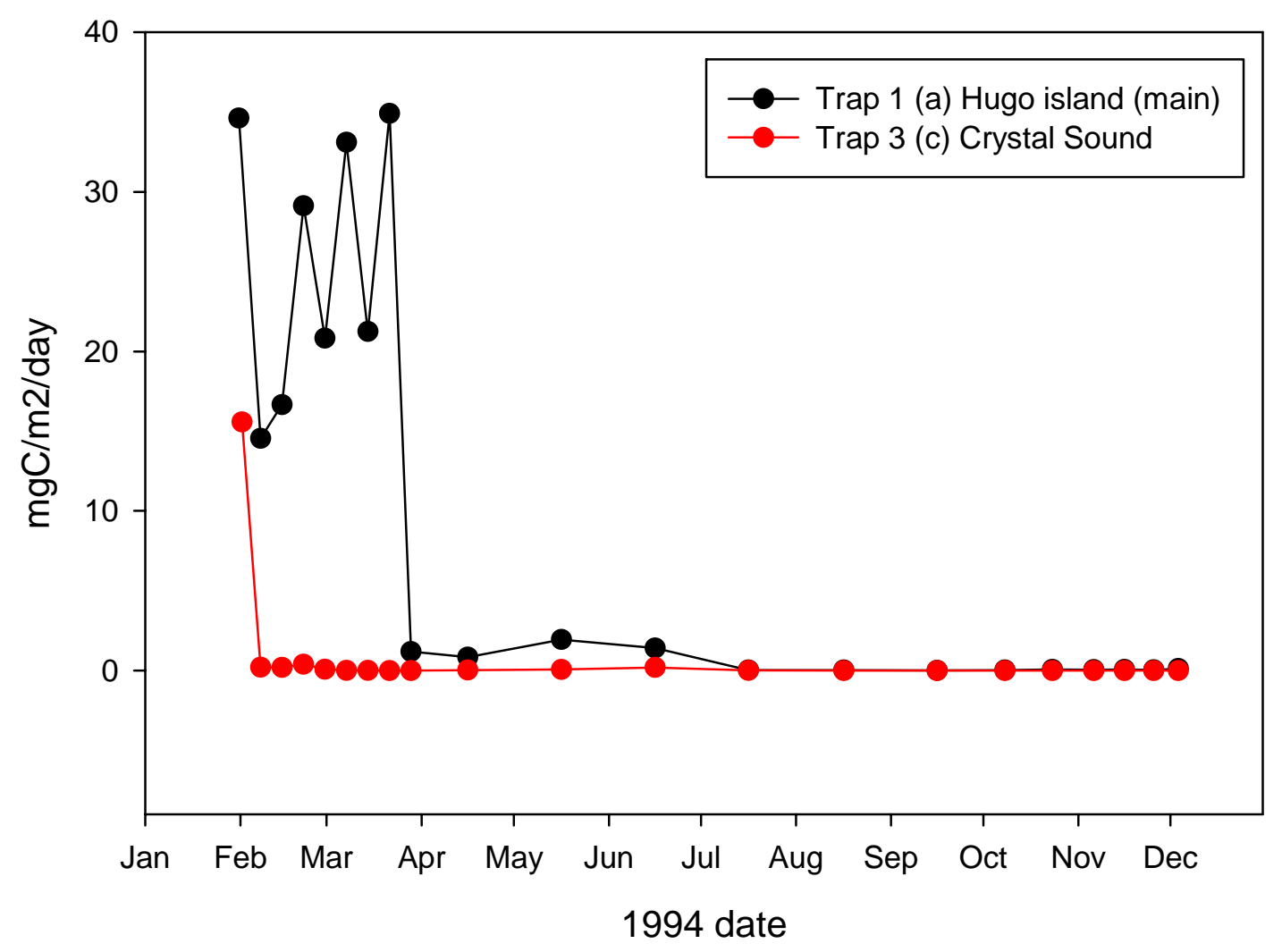


Deployment 4 ac

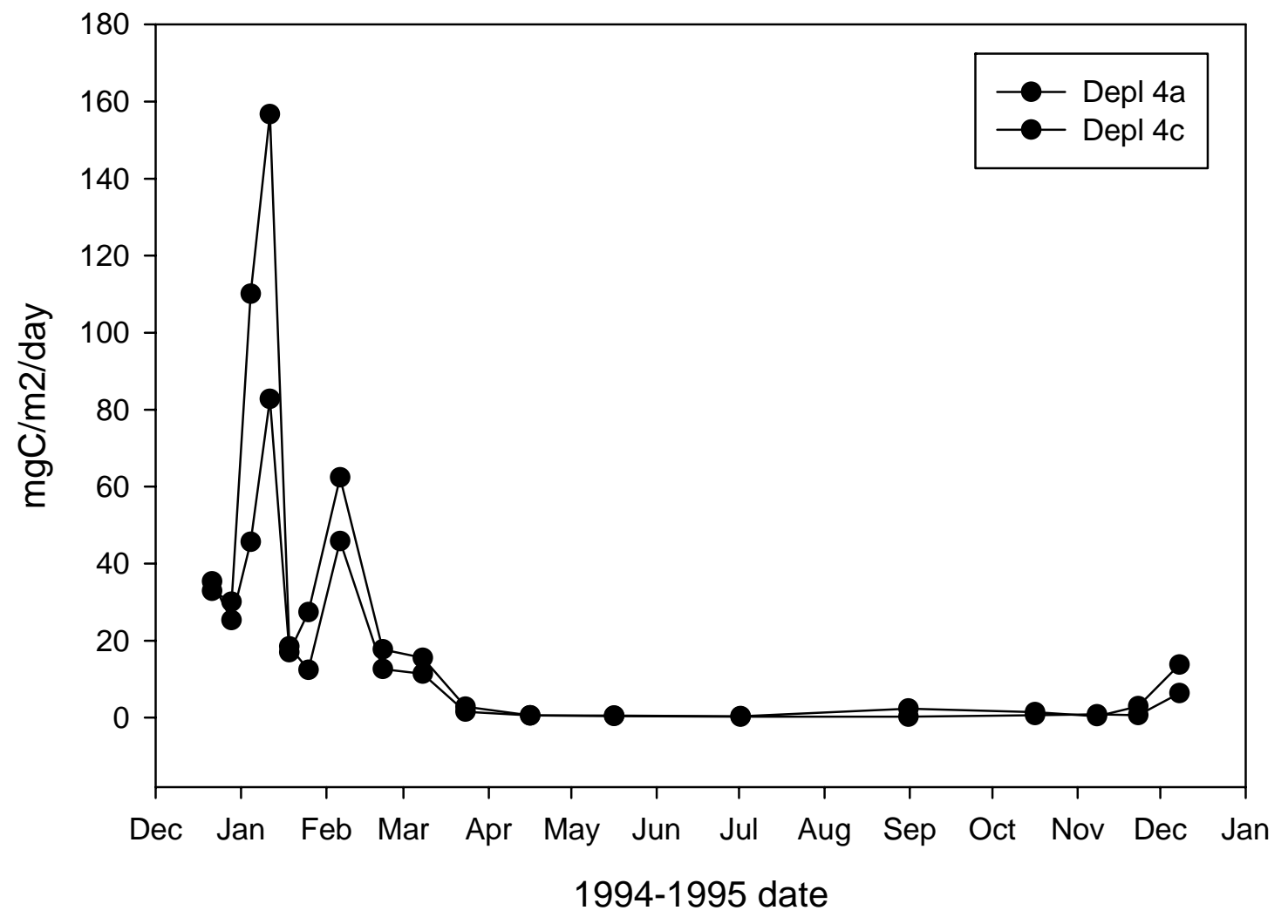


Deployment 5 ad

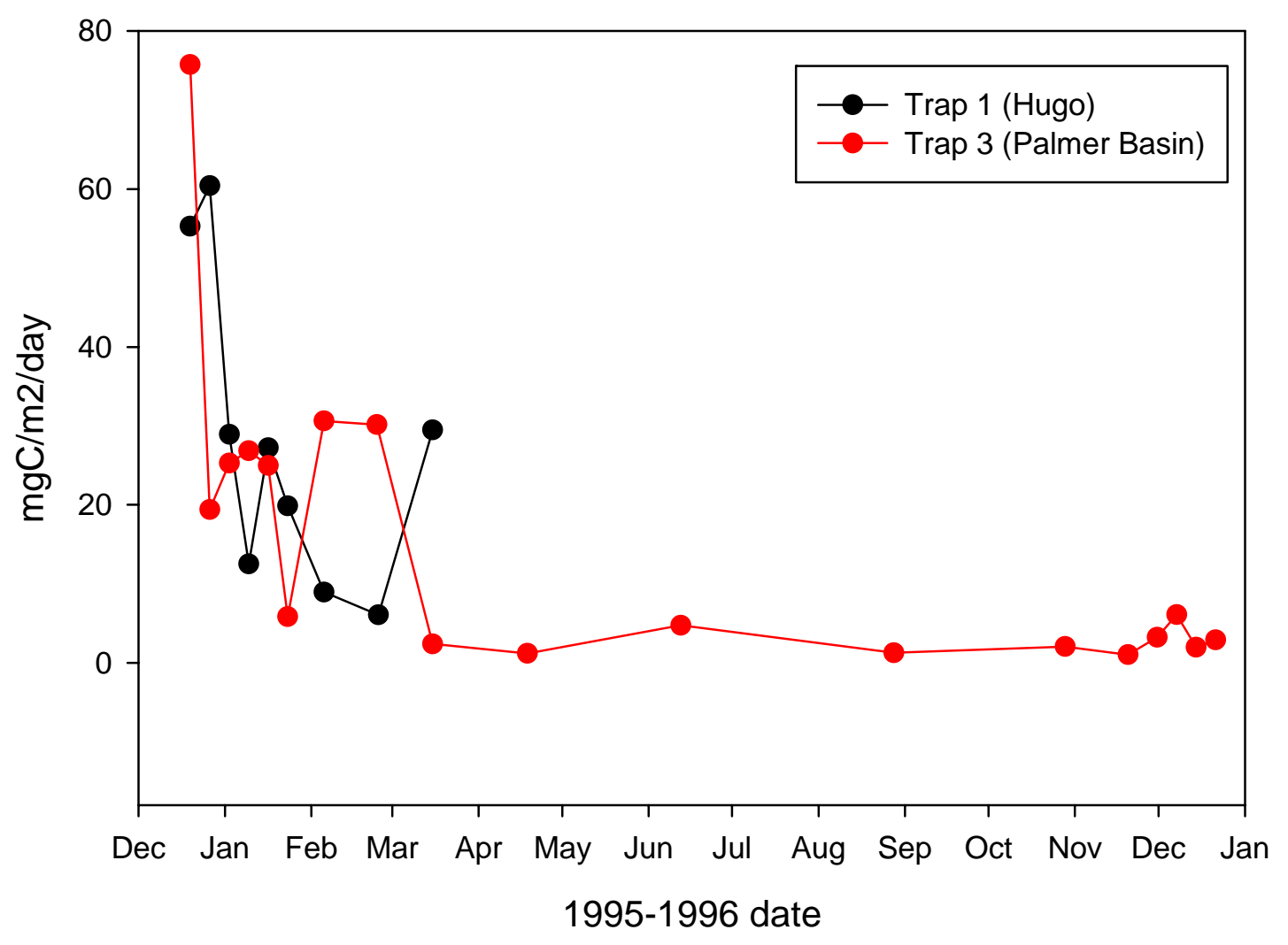




\section{Supplemental Materials 2 (Ducklow et al)}

\section{Hypothesis: A shift in the dates of sedimentation peals between 1993 - 2006.}

The hypothesis we tested is that there was a change in the sedimentation trap parameters after 1997 (strong ENSO event). All the parameters were split into two groups: (1993-1997) and (1998-2006) We used two-sided alternative hypotheses throughout the analysis and used a t-test (assuming equal and unequal variances) and a rank sum test (nonparametric). The test results were equivalent so we report only the t-test (assuming unequal variances).

Sediment trap parameters are:

day of peak maximum (peak.day)

day of start of peak (peak.start)

day of end of peak (peak.end)

duration of peak (peak.duration)

Int C/day

Duration is the number of days between the start and end of the peak. Total sedimentation was standardized on a per day basis because duration varied among years. Summary statistics for the parameters are in Table S1.

The two sediment trap parameters that were significantly different between periods were peak.day and peak.start (Table S2). The peak day in period 2 was about 40 days later compared to the peak day in period 1 . The start of the peak in period 2 was about 30 days later compared to the start of the peak in period 1 .

Peak.end, peak.duration and intC/day did not differ between periods (Table S2). Though the means for peak.end appear to be different between the 2 groups, the large amount of variability within the groups precluded detection of differences (Table S1).

Peak.end can be viewed as a composite variable: peak.end = peak.start + peak.duration. The difference between groups for peak start is about 30 days but the variability in peak.duration is 44-67 days. The variability in peak.duration overwhelms the difference in peak.start and we end up with a highly variable peak.end and no ability to detect differences between groups (given the sample size).

Table S1. Summary statistics of sediment trap parameters by period

\begin{tabular}{llrrrrr}
\hline Period & & peak.day & peak.start & peak.end & peak.duration & intC/day \\
\hline $1993-1997$ & mean & 367.8 & 343.2 & 449.6 & 106.4 & 1.52 \\
$(\mathrm{n}=5)$ & SD & 18.8 & 24.7 & 55.4 & 67.4 & 0.80 \\
& & & & & & \\
$1998-2006$ & mean & 410.6 & 373.4 & 479.1 & 105.7 & 1.73 \\
$(\mathrm{n}=7)$ & SD & 17.0 & 15.1 & 44.7 & 44.0 & 1.02 \\
\hline
\end{tabular}


Table S2. Results for t-tests using unequal variances for the sediment trap parameters

\begin{tabular}{lrrr}
\hline Variable & test-statistic & $\mathrm{df}$ & $\mathrm{p}$-value \\
\hline peak.day & -4.04 & 8.15 & 0.004 \\
peak.start & -2.43 & 6.14 & 0.05 \\
peak.end & -0.98 & 7.5 & 0.35 \\
peak.duration & 0.02 & 6.4 & 0.98 \\
intC/day & -0.41 & 9.8 & 0.69 \\
\hline
\end{tabular}

We then considered whether the ice parameters changed between periods. The ice parameters were:

day of ice advance around trap (ice.advance)

day of ice retreat around trap (ice.retreat)

ice duration (ice.duration)

Ice duration is the number of days between ice.advance and ice.retreat. Summary statistics for the ice parameters are in Table S3.

In the case of the ice parameters, there were no significant differences between periods (Table S4). There have been changes in ice advance and retreat over the period 1978 - present (Stammerjohn et al., this volume), but the small sample sizes in this analysis does not allow detection of differences within the larger trends.

Table S3. Summary statistics for the ice parameters by period:

\begin{tabular}{llrrr}
\hline Period & & ice.advance & ice.retreat & ice.duration \\
\hline $1993-1997$ & mean & 179.8 & 308.4 & 118.8 \\
$(\mathrm{n}=5)$ & SD & 8.6 & 16.9 & 33.1 \\
& & & & \\
$1998-2006$ & mean & 191 & 316.9 & 124.7 \\
$(\mathrm{n}=7)$ & SD & 24.1 & 24.8 & 44.0 \\
\hline
\end{tabular}

Table S4. Results for t-tests using unequal variances for the ice parameters

\begin{tabular}{|lrrr|}
\hline Variable & test-statistic & $\mathrm{df}$ & p-value \\
\hline ice.advance & -1.13 & 7.9 & 0.29 \\
ice.retreat & -0.7 & 10 & 0.50 \\
ice.duration & -0.26 & 9.9 & 0.80 \\
\hline
\end{tabular}


Using the conceptual model of ice extent \& retreat -> bloom -> sedimentation, we calculated the following ice-sedimentation variables:

elapsed time between ice advance and start of the peak(peak.start) and day of peak maximum (peak.day)

elapsed time between ice retreat and start of the peak (peak.start) and day of peak maximum (peak.day)

Summary statistics are in Table S5. Significant differences were seen with the time elapsed between the day of peak maximum and the ice parameters (Table S6). In period 2, about 30 more days elapsed after ice advance before peak sedimentation occurred compared to period 1; there was a tendency in period 2 for the day of peak maximum to occur about 35 days later after ice retreat than during period 1. No significant differences were found when considering time elapsed between the start of peak sedimentation and the advance/retreat of the ice.

Table S5. Summary statistics for ice-sedimentation variables.

\begin{tabular}{|c|c|c|c|c|c|}
\hline Period & & $\begin{array}{l}\text { peak.day-ice } \\
\text { advance }\end{array}$ & $\begin{array}{l}\text { peak.day- } \\
\text { ice.retreat }\end{array}$ & $\begin{array}{l}\text { peak.start- } \\
\text { ice.advance }\end{array}$ & $\begin{array}{l}\text { peak.start- } \\
\text { ice.retreat }\end{array}$ \\
\hline 1993-1997 & mean & 188 & 59.4 & 163.4 & 34.8 \\
\hline$(n=5)$ & $\mathrm{SD}$ & 16.7 & 19.0 & 25.0 & 17.2 \\
\hline 1998-2006 & mean & 219.6 & 93.7 & 182.4 & 56.6 \\
\hline$(n=7)$ & SD & 21.0 & 38.7 & 32.1 & 29.6 \\
\hline
\end{tabular}

Table S6. Results of t-tests using unequal variances for the ice-sedimentation variables.

\begin{tabular}{|lrrr|}
\hline Variable & test-statistic & df & p-value \\
\hline peak.day-ice advance & -2.89 & 9.8 & 0.02 \\
peak.day-ice.retreat & -2.03 & 9.2 & 0.07 \\
peak.start-ice.advance & -1.15 & 9.8 & 0.27 \\
peak.start-ice.retreat & -1.6 & 9.7 & 0.14 \\
\hline
\end{tabular}

